\title{
GEOLOGICAL ASPECTS ON THE SUSTAINABILITY OF ANCIENT AQUEDUCTS OF ATHENS
}

\author{
Chiotis D. E. ${ }^{1}$, Marinos G. P. ${ }^{2}$ \\ ${ }^{1}$ echiotis@otenet.gr, Tel. 210-8075945 \\ 2marinos@central.ntua.gr, EMП, Tel.210-7723430
}

\begin{abstract}
Geological aspects of the ancient aqueducts of Athens are examined with particular emphasis on the hydrogeological and geotechnical conditions which made possible their continuous function throughout the centuries up today. In particular, the sustainability of the Hymettos and the Hadrianic aqueducts is investigated and attributed to the capture of underground water and the skillful construction of the tunnels. The geometry of the Hadrianic aqueduct and the situation in the ancient tunnel are presented based on data obtained during the resumption of the ancient work in the 19th and 20th centuries. The up to forty meters deep wells along the tunnel continue to collect underground water at many places along the twenty kilometers long path of the Hadrianic aqueduct. Similarly, the Hymettos aqueduct still irrigates the National Garden with a daily rate of about one thousand cubic meters. The stability of the ancient tunnels is correlated with the surrounding geological formations; it turns out that the stability problems of the ancient tunnels are comparable to those met in the tunneling works of the Metro lines, particularly in the Athenian Schists. A new part of an ancient aqueduct was crossed during the Metro works which is considered to belong to the Hymettos aqueduct.
\end{abstract}

Keywords: Attica, Hadrian, Peisistratean, tunnel, groundwater.

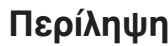

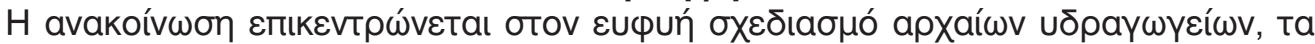

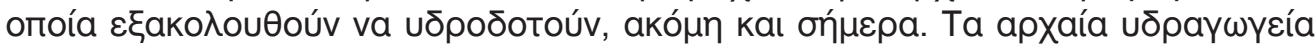

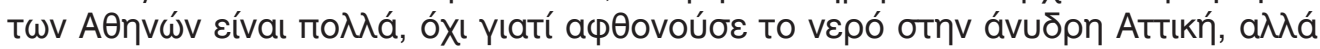

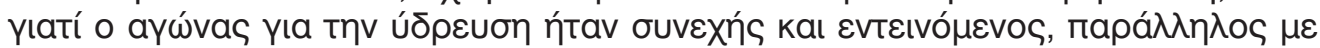

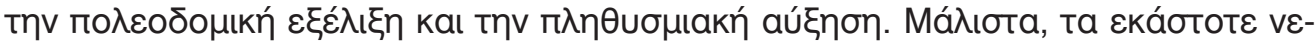

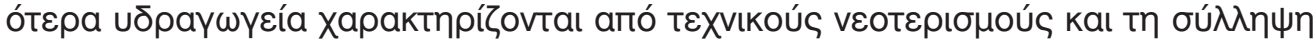

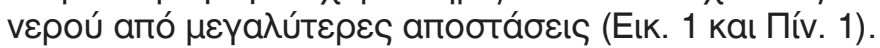

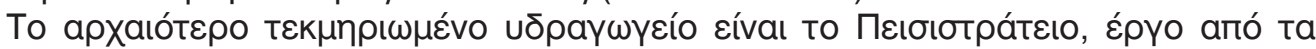

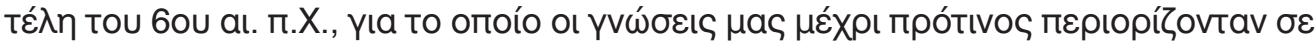

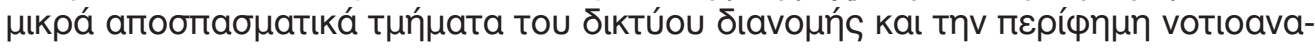

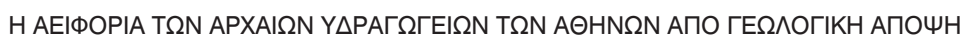

Хı́́tnc $\triangle$. E., Mapívoc $Г$. П. 


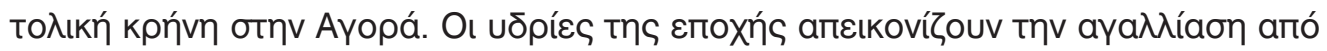

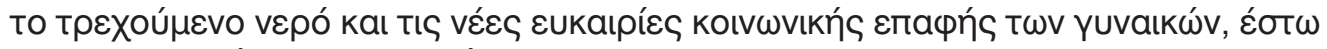

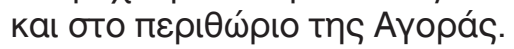

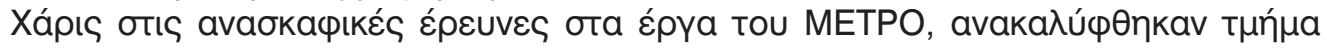

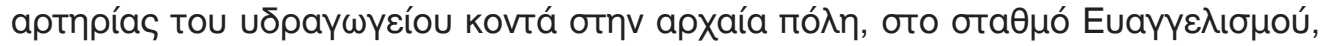

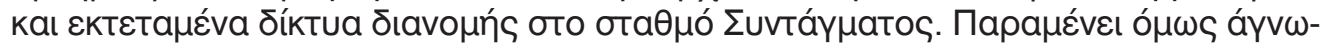

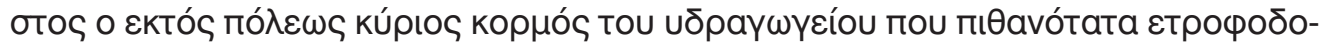

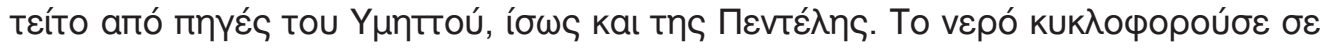

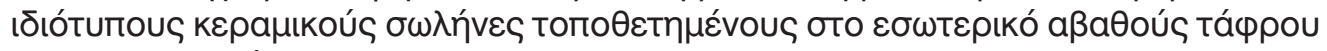

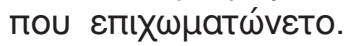

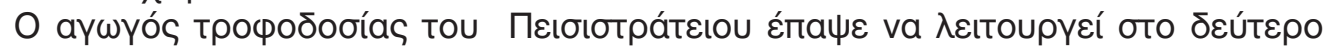

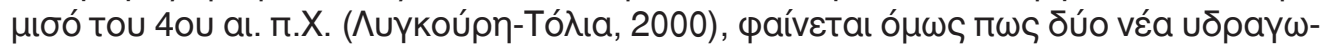

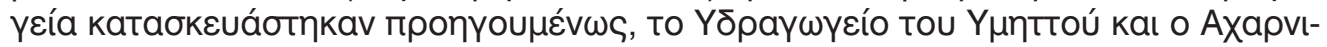

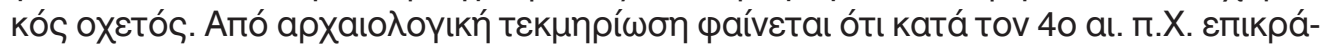

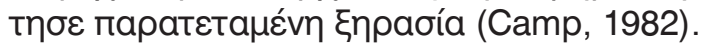

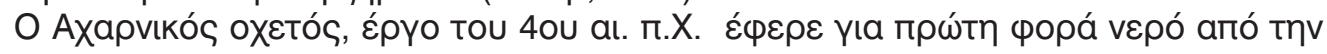

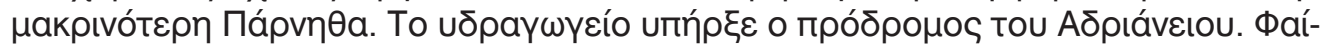

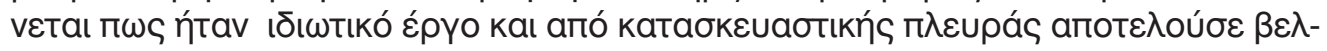

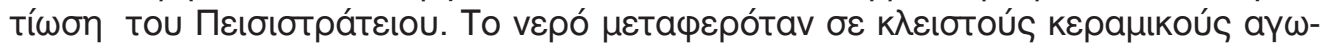

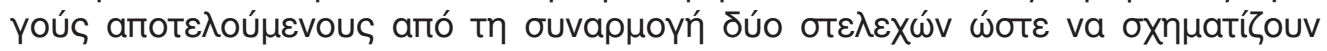

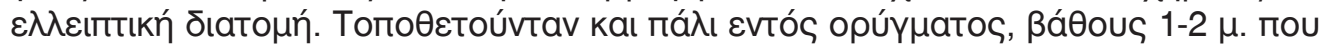

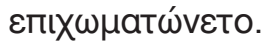

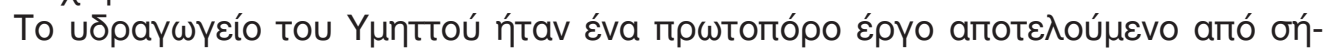

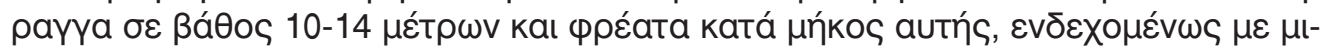

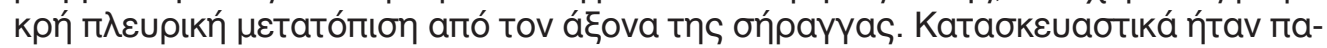

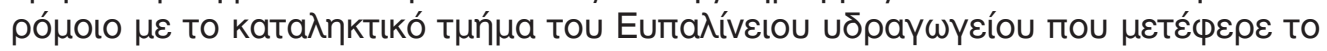

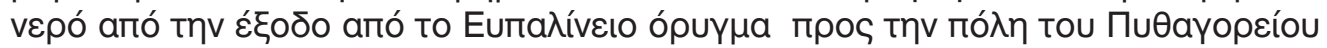

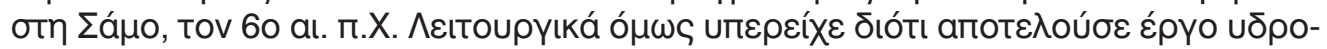

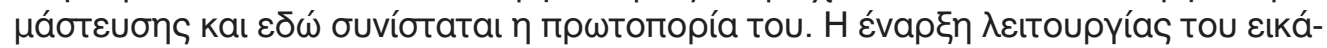

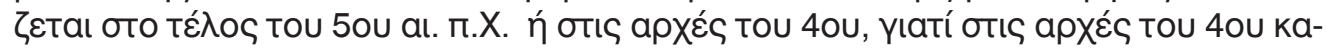

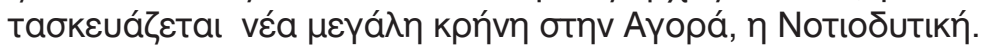

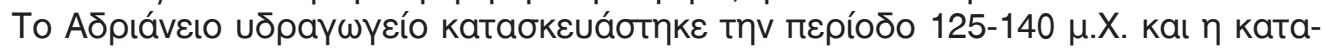

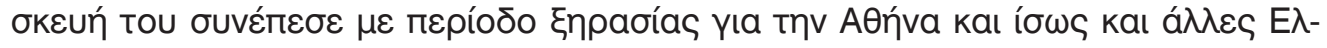

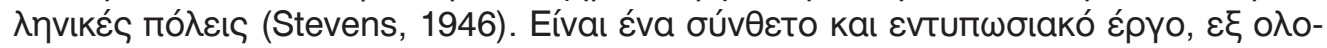

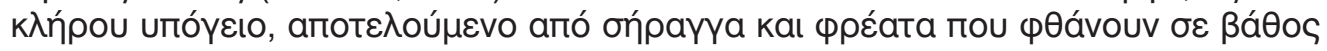

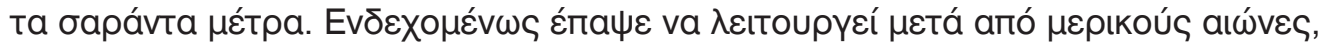

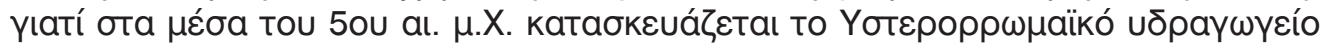
(Chiotis and Chioti, 2012).

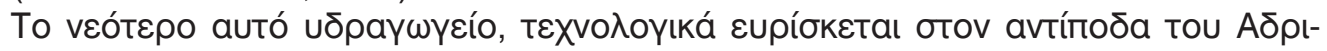

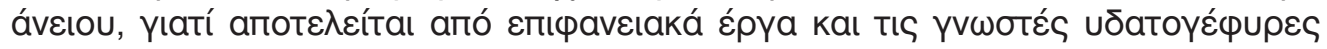

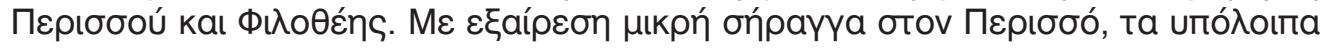

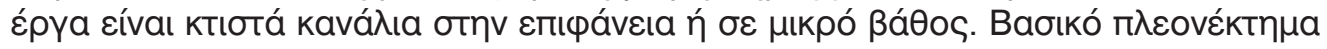

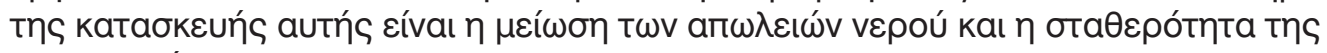
катабкєuńs.

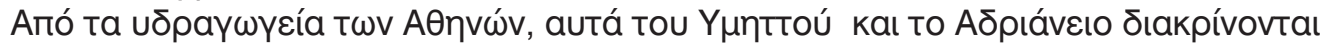

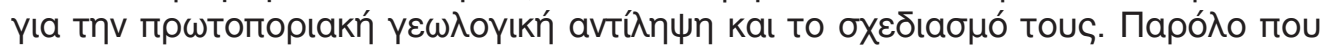




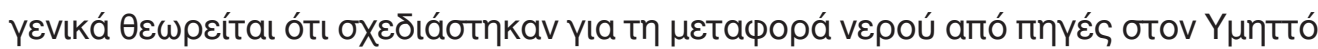

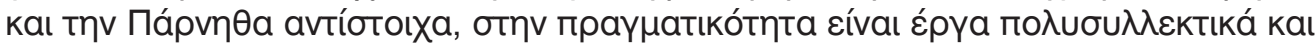

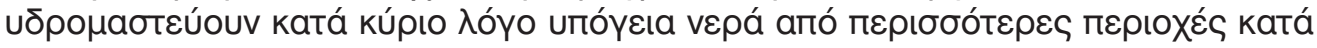

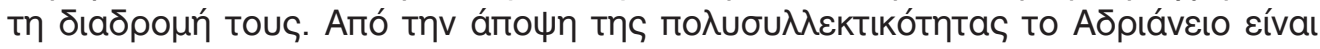

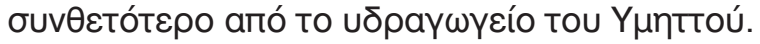

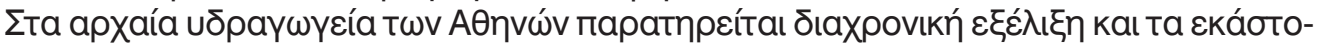

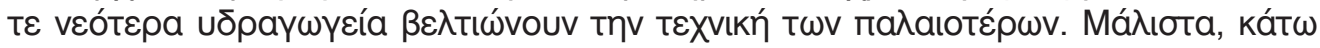

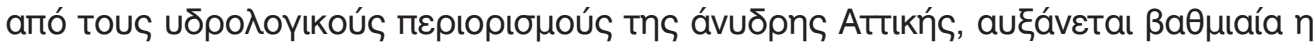

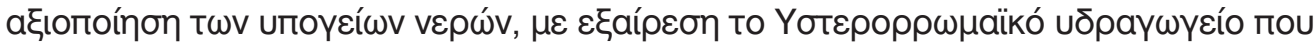

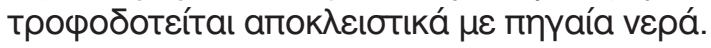

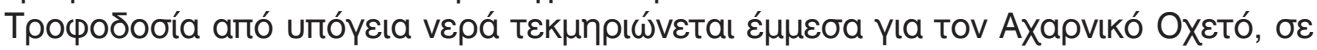

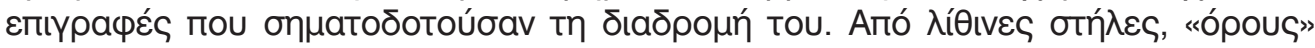

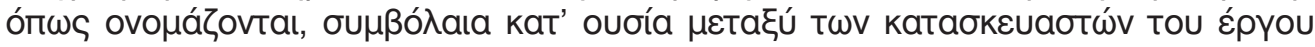

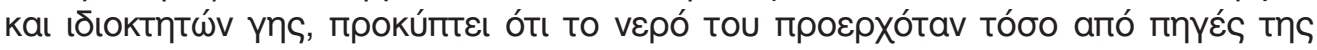

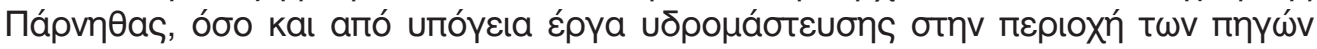
(Vanderpool, 1965).

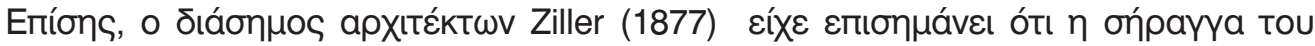

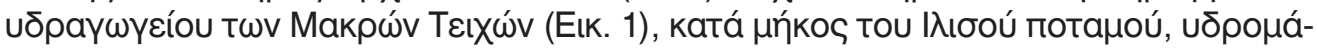

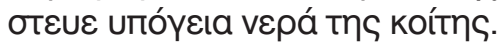

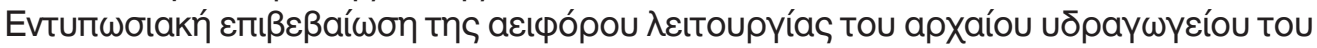

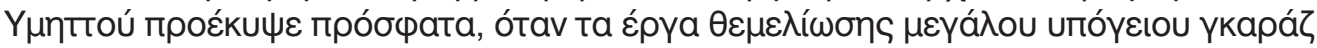

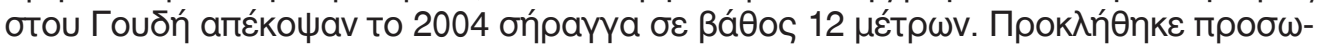

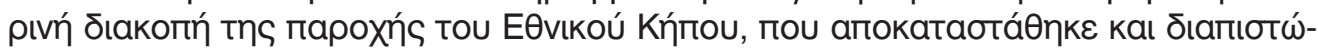

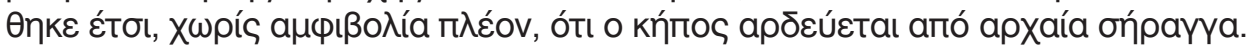

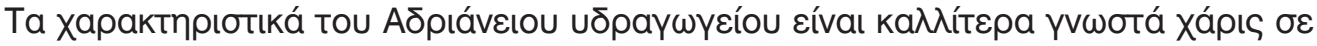

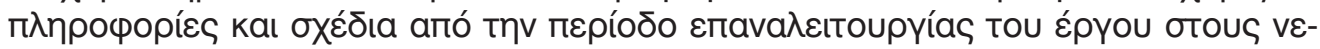

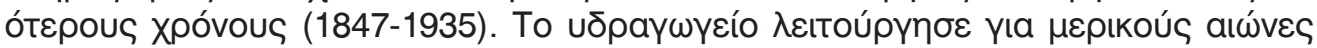

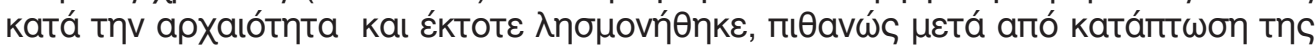

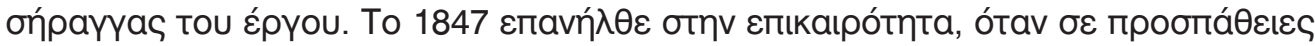

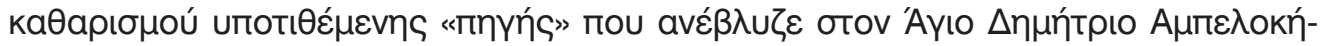

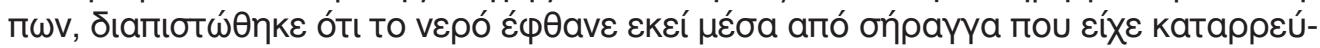

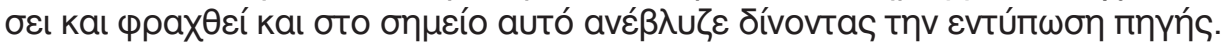

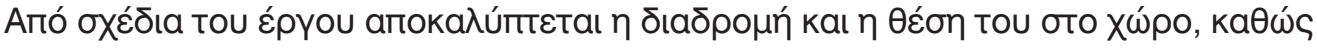

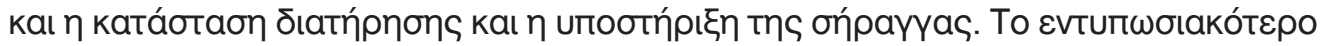

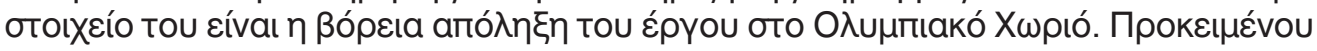

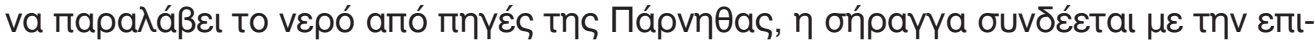

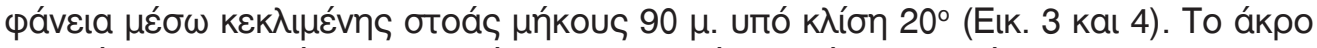

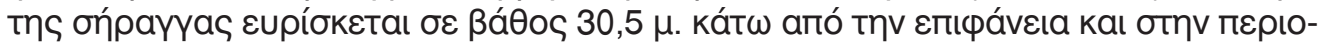

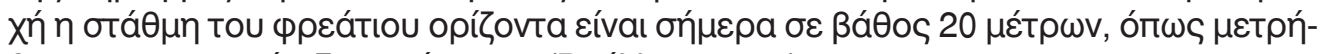

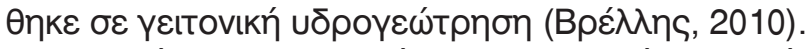

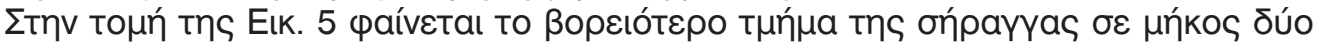

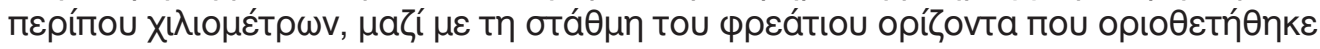

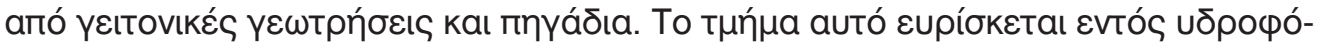

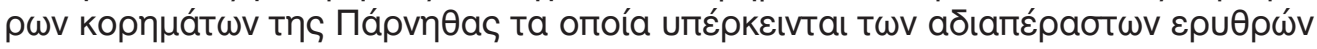

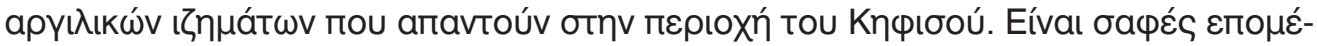

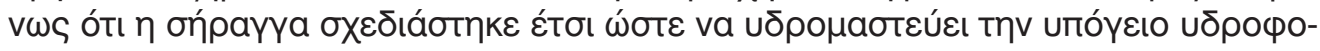




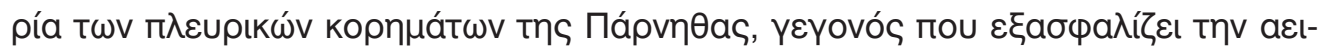

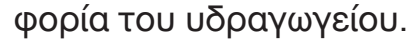

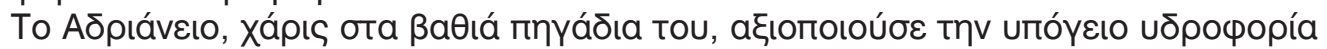

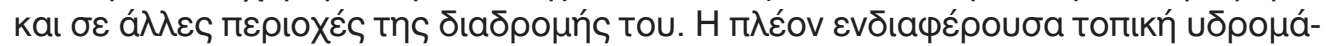

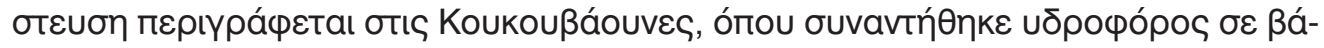

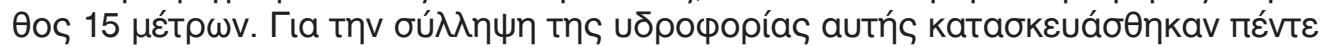

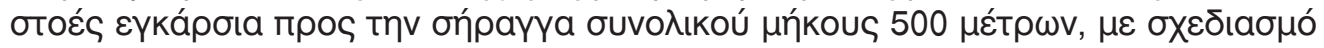

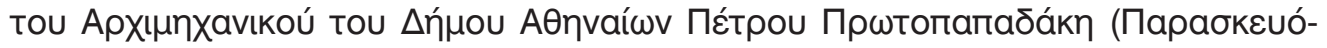
поU $\lambda$ о,, 1907$)$.

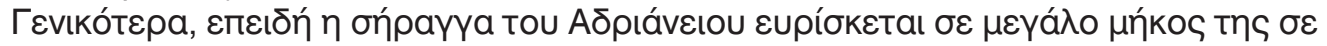

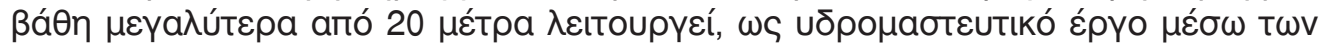

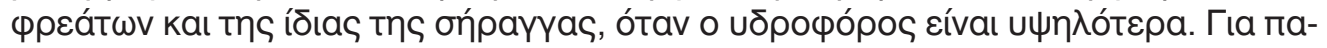

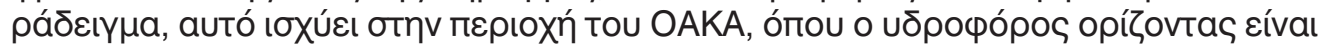

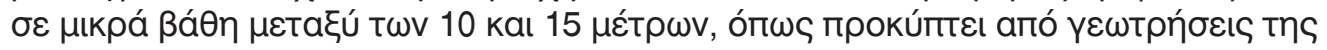

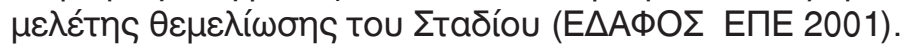

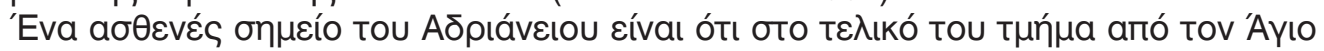

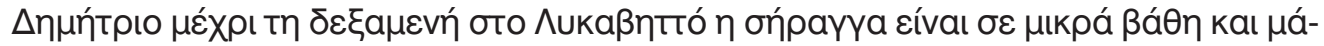

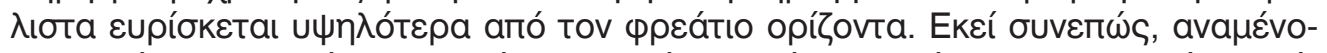

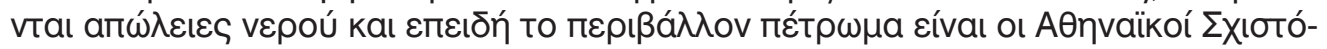

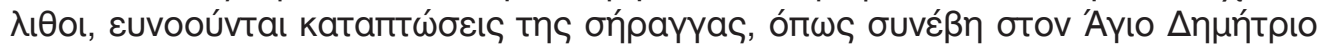
А

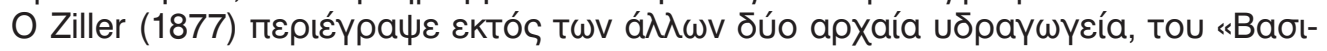

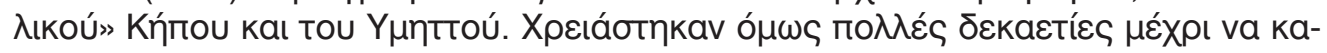

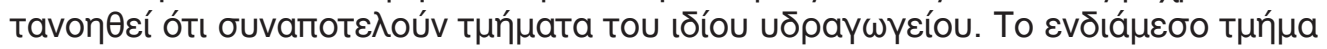

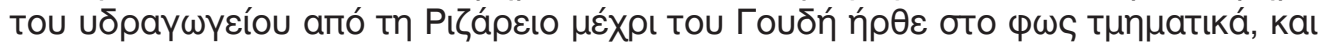

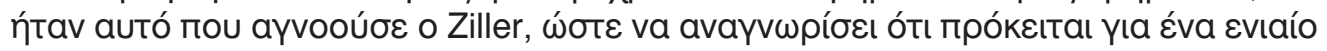

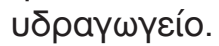

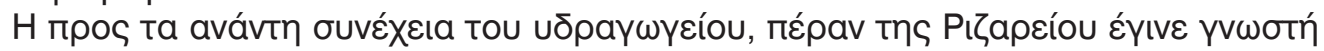

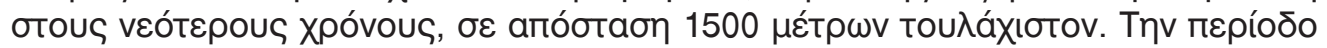

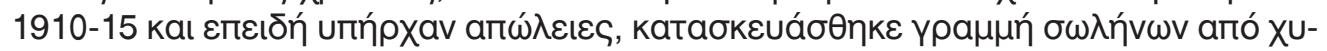

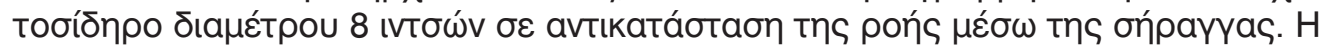

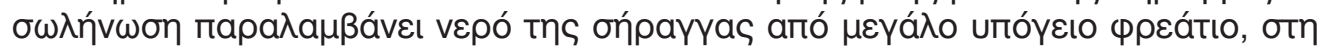

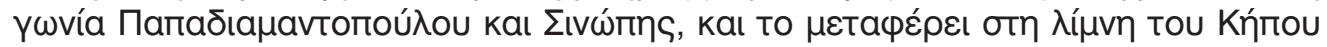

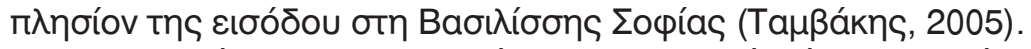

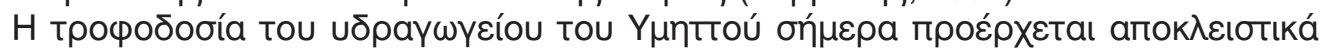

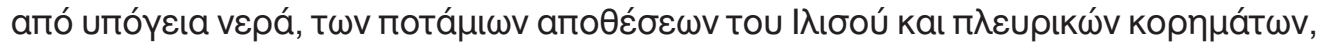

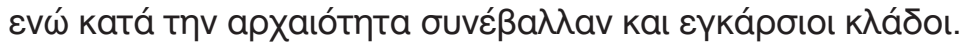

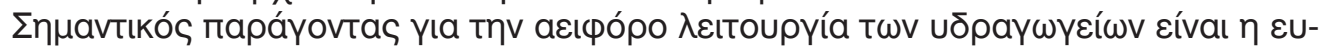

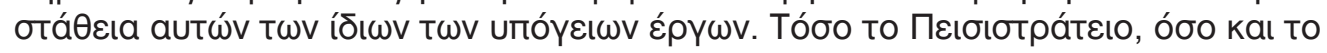

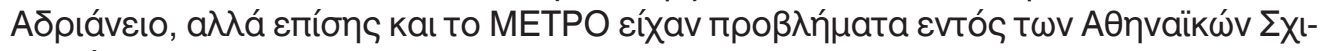

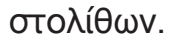

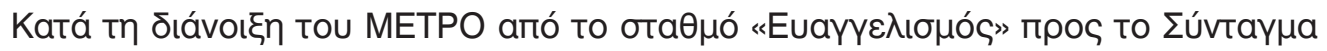

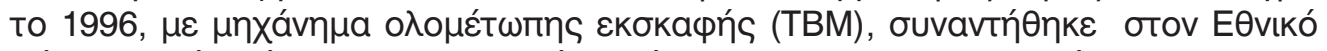

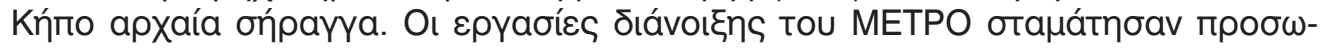

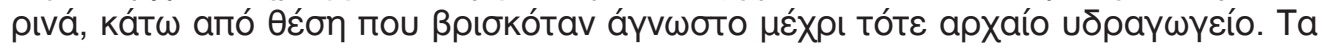

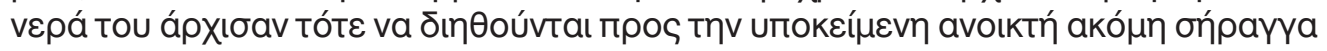




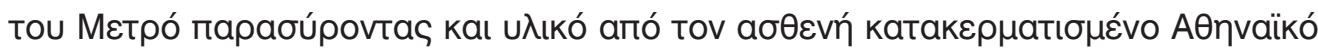

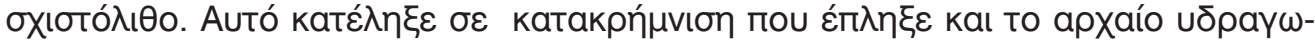

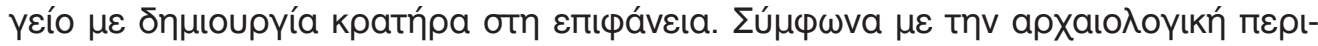

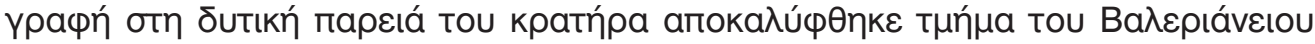

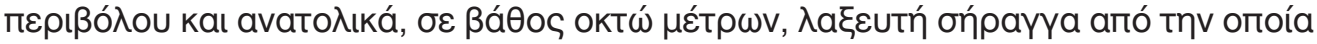

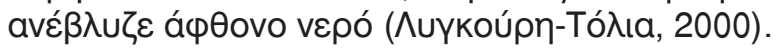

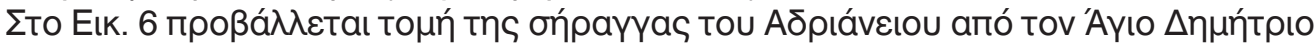
А

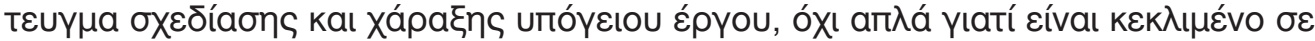
ó

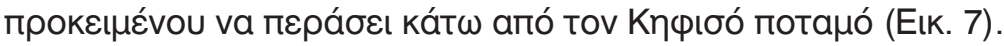

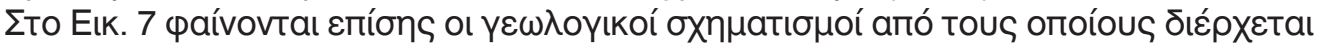

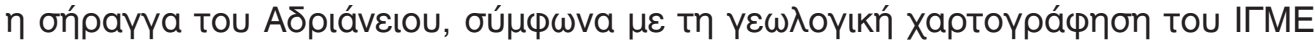

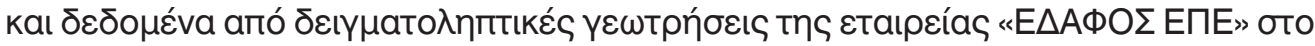

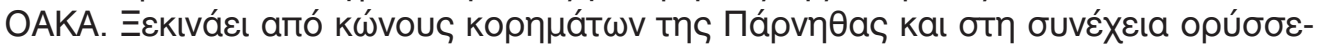

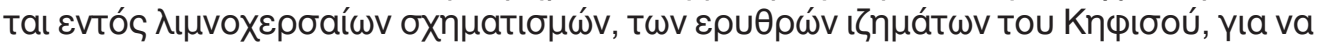

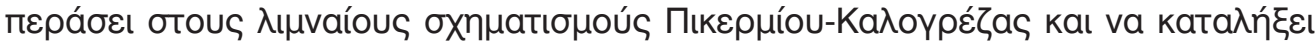

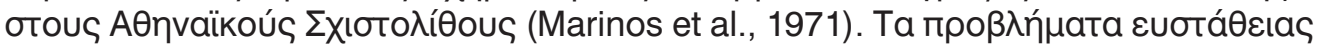

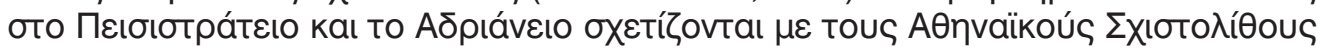

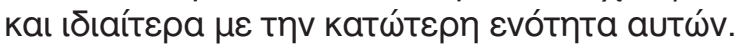

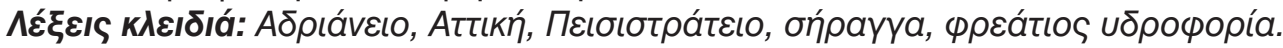




\section{Introduction}

The geological setting of the ancient aqueducts of Athens is examined with particular emphasis on the hydrogeological and geotechnical aspects. General features of the investigated aqueducts are summarized in the Tab. 1. A detailed description of the aqueducts, their approximate routes (Fig. 1) and the respective distri- bution nets were recently published with an extensive citation of references (Chiotis, 2011; Chiotis and Chioti, 2011; Chiotis and Chiot, 2012). The terminal parts of both the Acharnian and the Late Roman aqueducts are unknown and alternative traces of them have been drawn hypothetically in Fig. 1, i.e. the traces $3.1,3.2$ and $5.3,5.4$ respectively.

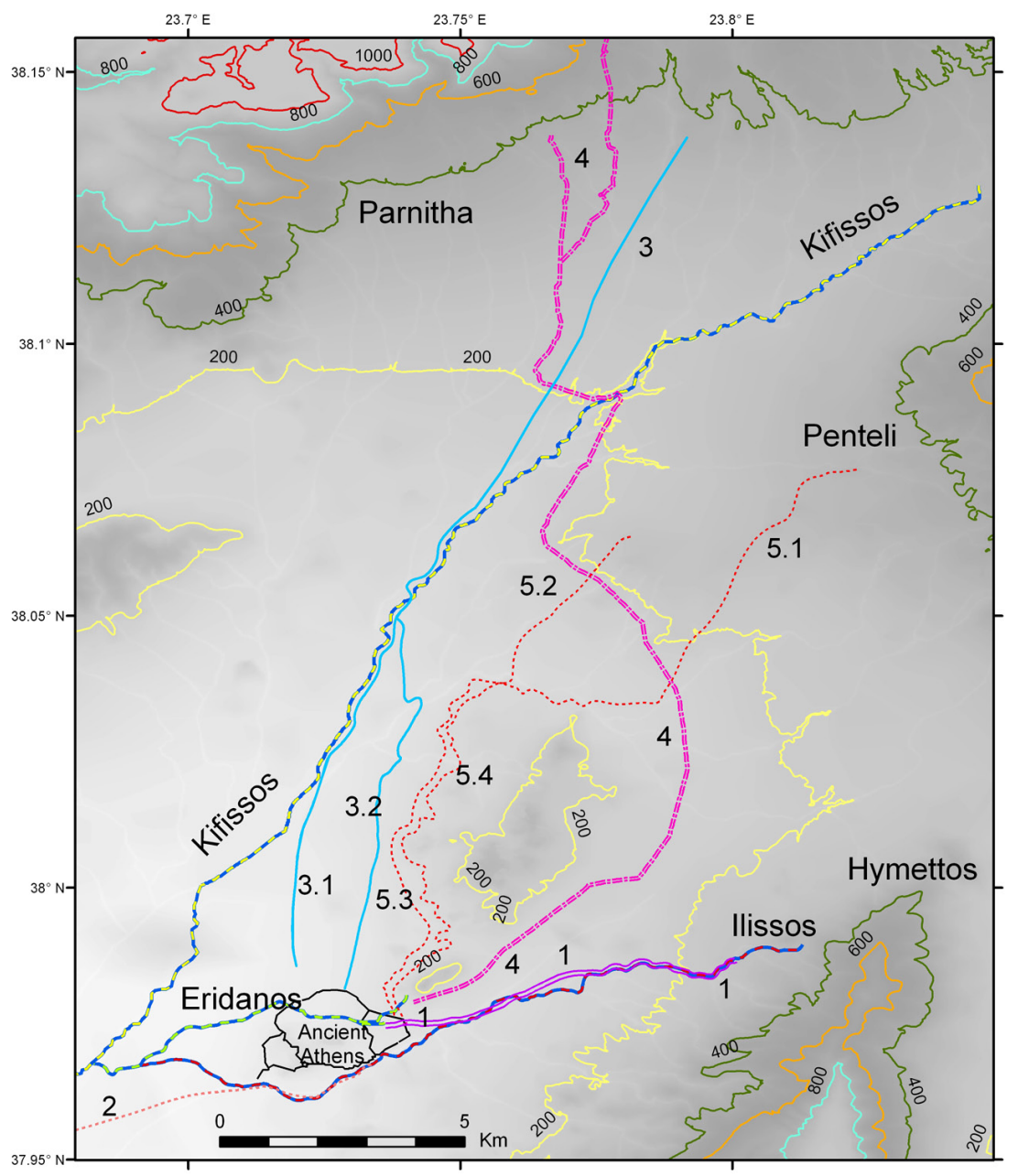

Fig. 1. The most significant ancient aqueducts of Athens: (1) Hymettos, (2) Long Walls, (3) Acharnian, (4) Hadrianic, (5) Late Roman: 5.1 Kifissia branch, 5.2 Herakleion branch. The identified part of the Peisistratean aqueduct is shown in Fig. 2 (Chiotis, 2011; Chiotis and Chioti, 2011).

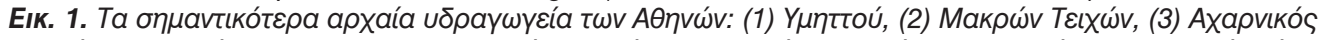

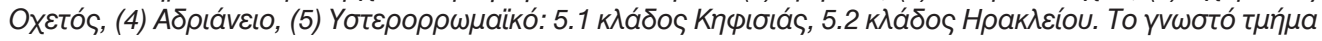

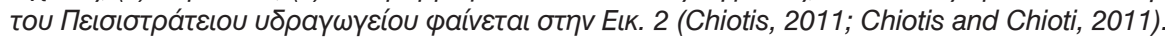




\begin{tabular}{|l|l|l|l|}
\hline Aqueduct & $\begin{array}{l}\text { Construction } \\
\text { period }\end{array}$ & Type of work & $\begin{array}{l}\text { Approx. } \\
\text { length, } \mathrm{km}\end{array}$ \\
\hline Peisistratean & $\begin{array}{l}\text { Late } 6^{\text {th }} \mathrm{C} . \\
\text { BC }\end{array}$ & $\begin{array}{l}\text { Terracotta pipes } \\
\text { in shallow trench }\end{array}$ & Unknown \\
\hline Hymettos & $\begin{array}{l}\text { Late } 5^{\text {th }} \text { or } \\
\text { early } 4^{\text {th }} \text { C. } \\
\text { BC (estimated) }\end{array}$ & $\begin{array}{l}\text { Tunnel and wells } \\
\text { up to } 14 \text { m deep }\end{array}$ & 6.5 \\
\hline Acharnian & $\begin{array}{l}\text { Early } 4^{\text {th }} \text { C. } \\
\text { BC }\end{array}$ & $\begin{array}{l}\text { Elliptical } \\
\text { terracotta tubes in } \\
\text { shallow trench }\end{array}$ & 19.5 \\
\hline Long Walls aq. & Unknown & $\begin{array}{l}\text { Shallow tunnel } \\
\text { and wells }\end{array}$ & $\sim 9$ \\
\hline Hadrianic & $\begin{array}{l}125-140 \text { AD } \\
\text { Late Roman }\end{array}$ & $\begin{array}{l}\text { Tunnel and wells } \\
\text { up to 40 m deep }\end{array}$ & 19.8 \\
\hline
\end{tabular}

Tab. 1. Characteristics of the most significant ancient aqueducts in Athens

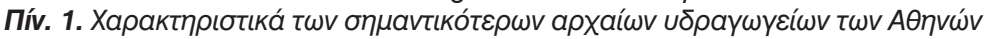

Some ancient aqueducts derived water exclusively from springs, whereas others combined water from springs and underground capture as well. Although spring water was preferred, it was not sufficient; the ancient aqueducts in Athens were intentionally designed to capture additional underground water, in order to increase the flow rate and reduce the effect of periodic fluctuations of the springs in the summer. It is thanks to the underground water drainage and the skillful construction of the hydraulic works, that the Hymettos and the Hadrianic aqueducts are still effective today. 


\section{The Origin of Water of the Ancient Aqueducts of Athens}

Many famous aqueducts in Greece simply carried water from springs; this was actually the case of the Eupalinian on Samos and the Roman aqueducts of Nicopolis and Corinth. For this reason, perhaps, it is commonly assumed that the ancient aqueducts of Athens were exclusively supplied from springs of the surrounding mountains. Thus, Tölle-Kastenbein $^{3}$ (1994) placed the start of the Hymettos aqueduct on the flanks of the Hymettos Mountain and suggested that the water of springs was collected in a reservoir before flowing in the aqueduct tunnel.

\subsection{General comments on the contribution of underground water in aqueducts of Athens}

No doubt, springs were also used but underground water was the dominant component for the Hymettos and the Hadrianic aqueducts. The latter, in particular, derived water from numerous resources, as can be documented today thanks to the data available from the recommencement of the aqueduct in the period 1847 to 1935 .

Underground water was also captured partly by the Acharnian aqueduct, a hydraulic work of the early fourth century $B C$ that brought water from springs in the foothills of the Parnitha Mountain. The upper part of the route of the Acharnian aqueduct, up to the Kifissos River, is known from excavations as well as from ancient inscriptions, referring to the terms of agreement between the commissioners of the aqueduct and the land- owners (Patonos-Yiota, 2004). According to these terms, the commissioners of the aqueduct are permitted to dig underground collecting galleries in the water-bearing strata near the springs at any place and to any depth that they see fit (Vanderpool, 1965).

The exploitation of water from the talus and torrential cones on the flaks of mountains was a very old approach mentioned already in the Epic of Gilgamesh, a legend attributed to the third millennium BC: "Gilgamesh is awesome to perfection. It was he who opened the mountain passes, who dug wells on the flank of the mountain." (Tab. 1, Kovacs, 1989). Even before that, in the Neolithic times the settlers around the hill of Acropolis already used to dig shallow wells (Camp, 1977). It was the famous architect Ziller (1877) who described that the Long Walls aqueduct drained water from the llissos River, along a tunnel situated 2-2.5 m below the riverbed. The tunnel was connected at regular intervals with shallow wells, shifted laterally a couple of meters from the riverbed. Ziller remarked that under these conditions the aqueduct needs no spring, since the tunnel below the riverbed can be actually regarded as a spring. $\mathrm{He}$ has also suggested that the tunnel supplied a channel installed in the space between the Long Walls to bring water to Piraeus.

An impressive confirmation of ancient aqueduct sustainability is the case of the National Garden in Athens. Until recently it had not been realized that the Garden is irrigated from an ancient aqueduct; the deep excavation for the foundation of a parking station in 2004 crossed and cut

\footnotetext{
${ }^{3}$ Tölle-Kastenbein (1994) misidentified the Hymettos aqueduct (No 1 in Fig. 1) with the Peisistratean one. The term Peisistratean is reserved here only for the aqueduct dated in the era of Peisistratos. An artery of the Peisistratean aqueduct was recently discovered in the METRO excavation; that is indeed dated to the late 6th century BC (Lygouri-Tolia, 2000).
} 
off the ancient tunnel and the Garden was temporarily deprived of the supply of water of unknown origin by then.

\subsection{The Hymettos aqueduct}

Ziller among others described two ancient aqueducts, named by him the Royal Garden ${ }^{4}$ and the Hymettos aqueduct. It took however some decades before it was recognized (Chiotis, 2011) that both of them compose parts of the same aque- duct referred here as the Hymettos aqueduct (No 1 in Fig. 1). The intermediate part between the Royal Garden and the Hymettos foothills, from Rizareios to Goudi, was located stepwise; it was the missing part ignored by Ziller that prevented him from realizing the continuity of this work. It consists of a tunnel, at a depth of 10-14 metres, and of wells sometimes shifted by a few metres form the axis of the tunnel.

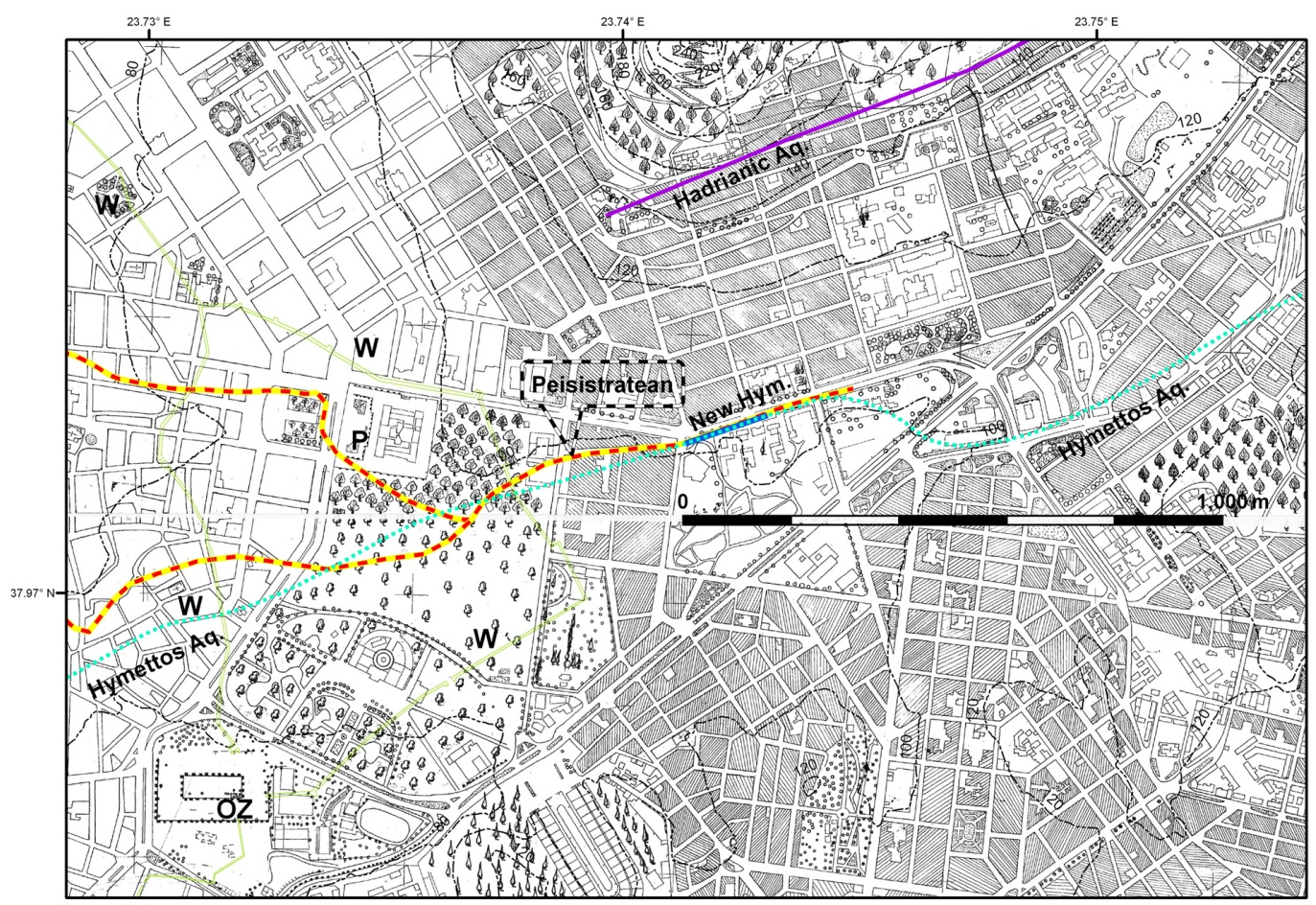

Fig. 2. The Hymettos and the Peisistratean aqueduct in the area of the National Garden. Part of the Hymettos aqueduct labelled "New Hym." is a new section located in 1996 during the Metro works. P: Parliament, W: ancient walls, OZ: Temple of Olympic Zeus.

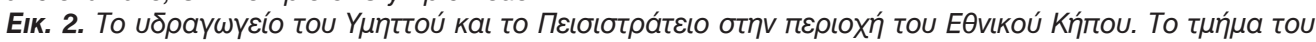

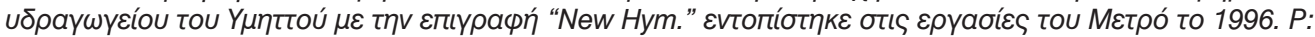

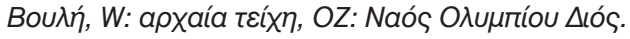


The aqueduct of the Royal Garden was discovered by the Director of the Garden in 1850 . The wells were plugged by silt at this time and the water level was about six meters higher than the tunnel floor (Ziller, 1877). It is worth mentioning two wells of special interest for historical reasons; in one of them a steam pump was installed in Queen's Amalia time; the pump failed to operate and was abandoned. A donkey wheel was assembled in an adjacent well, until an electric pump was installed in 1926; this historical well is still maintained today, surrounded by a kiosk.

Due to water leakage in the tunnel of the Hymettos aqueduct, a section of it about 1.5 kilometres long upstream from the Garden was abandoned and the water was switched to a pipeline in the period 1910-15 (Tamvakis, 2005).

A new point of the Hymettos aqueduct route was identified in 1980, when traces of oil were observed in the water of the Garden and funny comments of oil discovery were rumored. Finally, it was recognized that the soldiers of a military unit at Goudi had rejected oil waste in a well, which belonged to the aqueduct. The origin of the water of the Garden from an ancient tunnel was beyond any doubt confirmed in 2004, when the excavation for the foundation of a parking station cut off a tunnel at 12 meters below the surface. Thus, the water flow to the garden was interrupted, until the tunnel was restored and the flow rate returned to its normal level of $1050 \mathrm{~m}^{3}$ daily (Tamvakis, 2005).

The Hymettos and the Peisistratean aqueducts in the area of the National Garden are shown in Fig. 2. Part of the ancient tunnel, indicated as "New Hym." in Fig. 2, was traced by the authors for a distance of 150 metres along the Metro line; it is tentatively considered as a new discovery of the Hymettos aqueduct. Despite the adjacent projections on the map of the Peisistratean and the Hymettos aqueduct, they differ significantly in space, since the Peisistratean was constructed near the surface of the ground, whereas the Hemyttos aqueduct was dug about ten to fourteen metres below the surface.

Since no spring discharges presently into the Hymettos aqueduct, it is inferred that the water is of underground origin, associated with the Ilissos River sediments and the talus and scree cones on the flanks of the Hymettos Mountain. Despite Ziller's documented arguments on the importance of this aqueduct, no effort was undertaken to clean and restore it, as was done with the Hadrianic aqueduct.

\subsection{The Hadrianic aqueduct}

The Hadrianic aqueduct is better known thanks to the resumption of the work in the period 1847-1935. The route of the tunnel, the location of the wells, the state and the support of the tunnel, are described in the plans of the project, available to the authors from EYDAP (Water Supply and Sewerage Company S.A.). It was constructed in the period $125-140$ $A D$; it operated for some centuries and was forgotten for long. It was brought to light again in 1847, during the works for cleaning a supposed "spring" near Agios Dimitrios, Apmelokipoi. It was then understood that the water surged from a tunnel the roof of which had collapsed. It took some decades for the rehabilitation of the work which starts from the Olympic Village near the foothills of Parnitha and terminates in the ancient cistern at Kolonaki, Athens.

The aqueduct is underground all along its route, about 20 kilometers long; it comprises more than 400 wells along a 
tunnel 0.8 to $0.9 \mathrm{~m}$ wide and 1.6 to $1.8 \mathrm{~m}$ high. The average distance of the wells is 37.5 metres. The ancient waterbridges at Filothei and Perissos are not parts of the Hadrianic aqueduct as habitually considered; they belong to the branches of the Late Roman aqueduct, No 5.1 and 5.2 respectively in Fig. 1 (Chiotis and Chioti, 2011).

Thanks to the plans and sections of the aqueduct dated from the beginning of the past century the tunnel can be confidently correlated with the geological formations and the level of the water table. Representative parts of such unpublished sections from the archives of EYDAP are presented in the following Figs 8 to 11. A unique feature of the aqueduct is the northern part of the tunnel near the Olympic Village, where a gallery $90 \mathrm{~m}$ long, dipping 200, connects the tunnel with the surface (Fig. 3). The function of this gallery was to direct the water from the springs on the flanks of Parnitha into the tunnel by means of two channels as shown in Fig. 4.
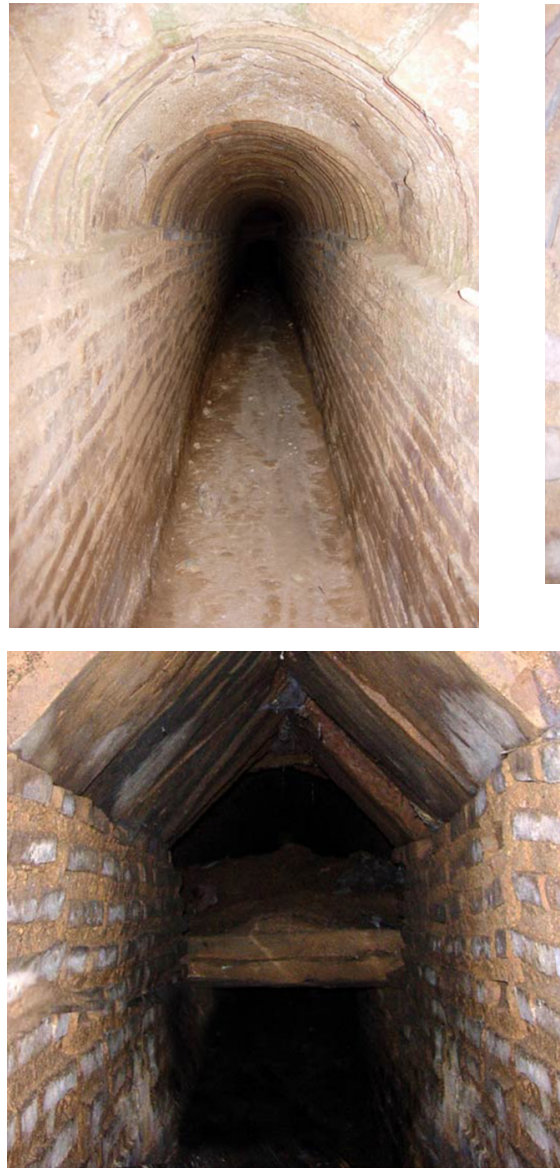
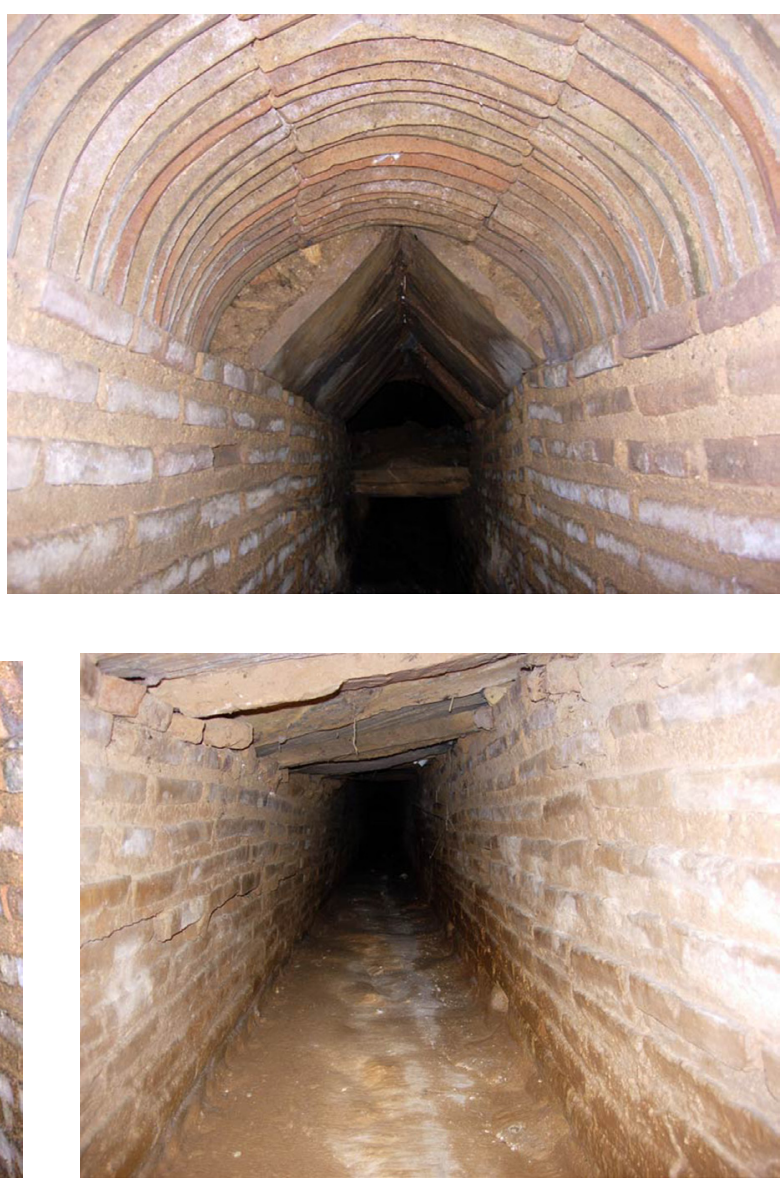

Fig. 3. The inclined gallery of the Hadrianic aqueduct at the Olympic Village; various types of support with standarized bricks are shown (Horne, 2009).

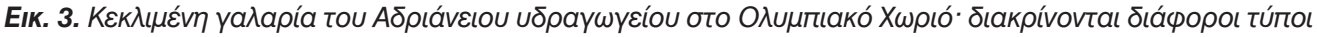

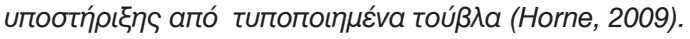




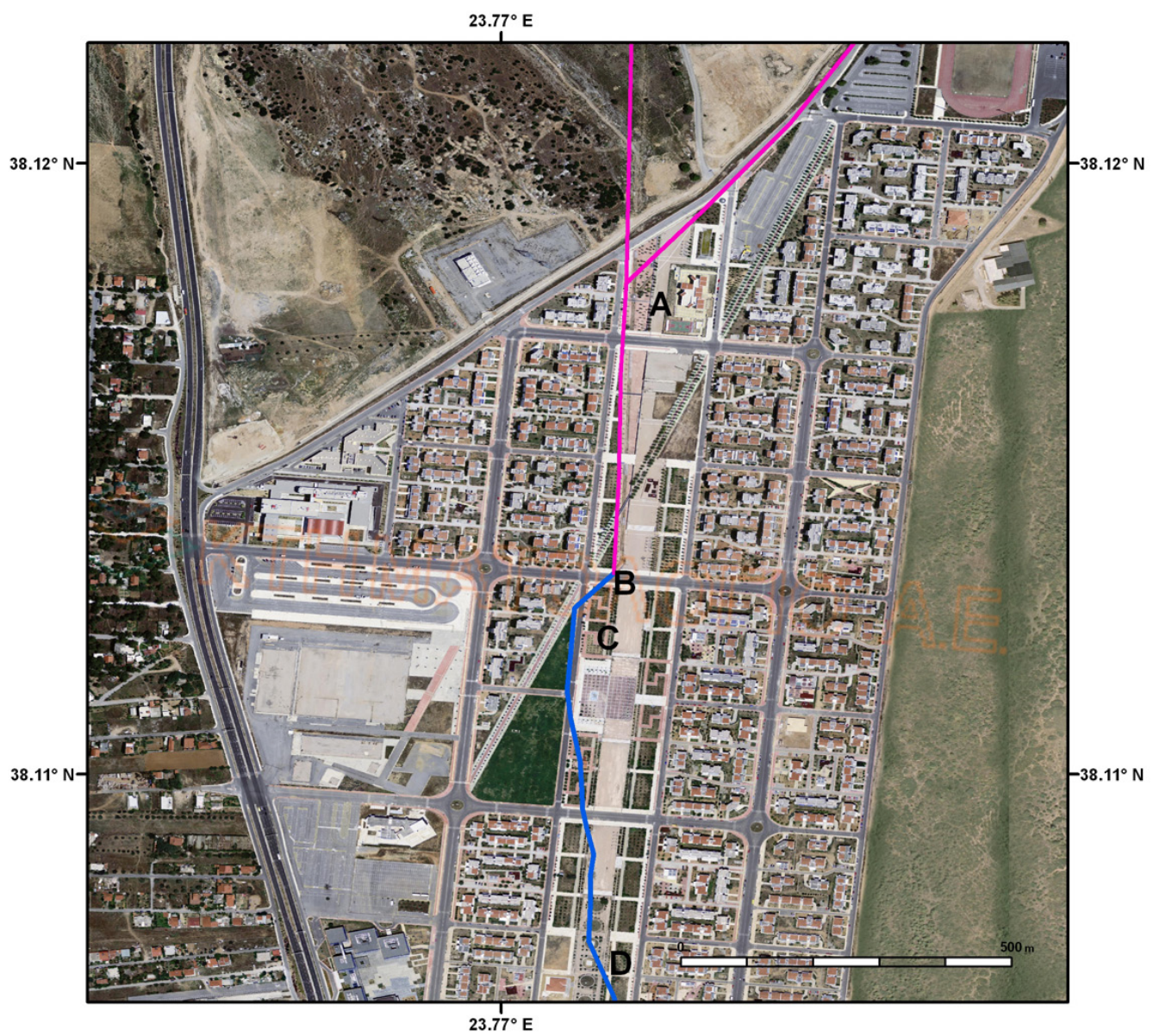

Fig. 4. Olympic Village: channels supplying water from springs converge at point $A ; B C$ and $C D$ are the projections on the ground of the inclined gallery and the northern part of the Hadrianic tunnel respectively.

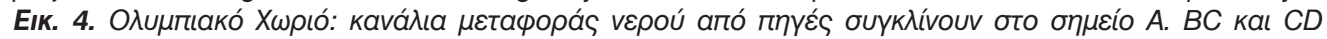

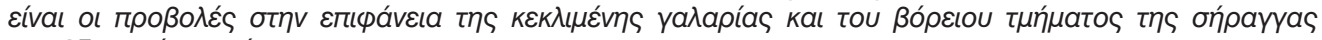

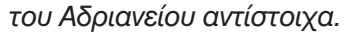

A revealing feature of the aqueduct's design is that the northern end of the tunnel lies ten metres below the underground water level, since it is found 30.5 metres below the surface at a place where the water table is at the depth of 20 metres, as measured at an adjacent borehole (Vrellis, 2010). Actually, the northern part of the tunnel was dug below the water table over a length of about $800 \mathrm{~m}$; the water table, shown in Fig. 5, was traced on the basis of adjacent modern boreholes and shafts reported by Siemos and Michalaki (2009).

This part of the tunnel is totally within water-bearing formation of breccia which overlies impermeable red argillaceous sediments outcropping southwards along the Kifissos River. 


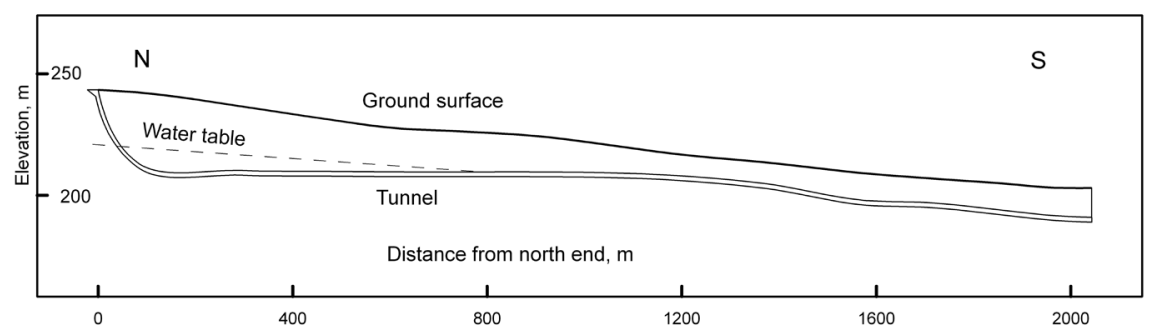

Fig. 5. Section along the northern part of the Hadrianic aqueduct depicting the ground surface, the water table, the inclined gallery and the aqueduct tunnel.

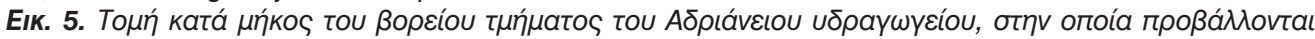

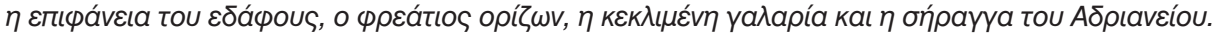

The underground water of the breccias near the northern end of the Hadrianic tunnel was also captured in 1901-03 by digging seven shafts $33 \mathrm{~m}$ deep connected with a tunnel $320 \mathrm{~m}$ long. The project was undertaken by the Chief Engineer of the Municipality of Athens Petros Protopapadakis; it yielded an additional rate of about $740 \mathrm{~m} 3$ daily (Paraskevopoulos, 1907).

Aquifers found along the route of the aqueduct were also drained during the resumption of the work; such was the case at the location No 8 (Fig. 6) at Koukouvaounes (Paraskevopoulos, 1907), $15 \mathrm{~m}$ below the surface and a few meters above the tunnel floor. Five galleries, of a total length of $500 \mathrm{~m}$, were dug at this place perpendicular to the aqueduct early in the 1900's and this supplied an additional 740 $\mathrm{m} 3$ daily in the summer period. More locations with transversal galleries are noted in the sections of the project.

Since the aqueduct floor is at a depth more than $20 \mathrm{~m}$ over a considerable distance, the chances of crossing and capturing groundwater aquifers are favourable. This is the case, for example, in the Olympic Athletic Centre of Athens (OAKA), where the level of water table is in general less than $15 \mathrm{~m}$, as measured in geotechnical boreholes (EDAFOS Ltd 2001).

The tunnel walls collapsed often during the resumption of the aqueduct in the nineteenth century and this caused a fluctuation of the flow rate, as indicated in the Tab. 2. A systematic support of the tunnel was undertaken during 1900-1901 and this improved the water output. After that, the average daily contribution of the Hadrianic tunnel itself was about $7000 \mathrm{~m} 3$ in the summer period. It is noted that the aqueduct also tapped water from other areas, and mainly from Penteli through the Chalandri stream. It is unknown whether the aqueduct collected water from the Kifissos River in antiquity, which was then a common practice.

\begin{tabular}{|l|l|l|l|l|l|l|l|l|l|l|}
\hline Year & 1862 & 1876 & 1887 & 1889 & 1896 & 1899 & 1901 & 1903 & 1905 & 1906 \\
\hline $\begin{array}{l}\mathrm{m}^{3} \text { per } \\
\text { day }^{5}\end{array}$ & 590 & 2400 & 5900 & 3500 & $\begin{array}{l}4800- \\
5160\end{array}$ & $\begin{array}{l}740- \\
1100\end{array}$ & $\begin{array}{l}2950- \\
5160\end{array}$ & $\begin{array}{l}4060- \\
8110\end{array}$ & $\begin{array}{l}9960- \\
17700\end{array}$ & $\begin{array}{l}7000- \\
11430\end{array}$ \\
\hline
\end{tabular}

Tab. 2. Water output of the Hadrianic aqueduct (Paraskevopoulos, 1907).

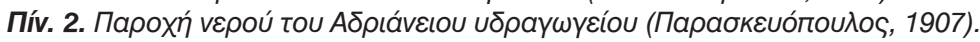

${ }^{5}$ The original values are reported by Paraskevopoulos (1907) in "okades", a Turkish unit of flow rate equal to $368.84 \mathrm{~m} 3$ per $24 \mathrm{~h}$, after Cordellas (1879). 


\section{The Stability of the Ancient Aqueducts}

The Hadrianic aqueduct provides useful evidence for the support technique of the tunnel walls. Stable parts were left unsupported; bricks of standard dimensions were used for the support in unstable formations, as shown in Fig. 3 at the inclined gallery at the Olympic Village. The walls were built with rectangular bricks and mortar, whereas the support of the roof was adjusted to local conditions. Arched support of the roof was most common in sections with stable rocks without roof caving, since this type of support requires a tight contact of the tiles with the roof. It seams that large oblique terracotta plates were used in locations with roof caving, where the direct contact with the roof was impossible. In modern times walls of masonry and roof of oblique marble plates were used, until concrete was introduced in the 1930's.

\subsection{Stability problems of the Hadri- anic tunnel}

The longitudinal section of the tunnel, based on the EYDAP drawings of the past century, reveals a remarkable consistency of the slope, $2.1 \%$ in average, despite local fluctuations (Fig. 6). The tunnel inclination from the bottom of the first well at $211.9 \mathrm{~m}$ in the northern end is about $2.5 \%$ over a length of $1.5 \mathrm{~km}$; then comes the steepest section up to the Kifissos River with an average dip of $13 \%$ o over a path of $2.5 \mathrm{~km}$ and finally the inclination is maintained more or less constant at $2.2 \%$ o for the rest $16 \mathrm{~km}$ beyond the Kifissos River. The Hadrianic tunnel terminated at the ancient cistern on the Lycabettus hill at an elevation of $133.37 \mathrm{~m}$ on the floor (Chiotis and Chioti, 2012). The geometric perfection is impressive for the additional reason that the tunnel had to follow a tortuous path in order to pass a few meters below the Kifissos River (Fig. 7). The descriptions on the drawings for the situation of the tunnel can be better appreciated by the correlation with the geology.

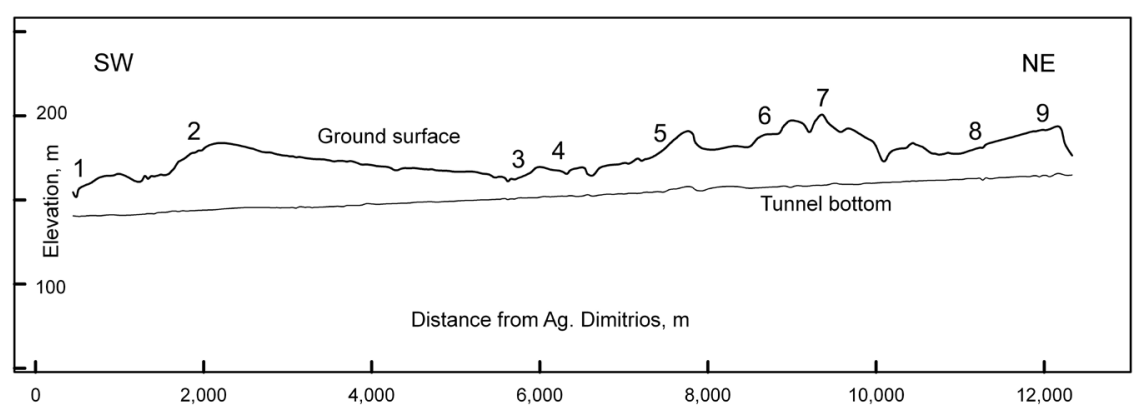

Fig. 6. Longitudinal section along the Hadrianic tunnel: from Ampelokipoi (1) to Pyrna-Kalyftaki, Kifissia (9); the chainage from Agios Dimitrios (Ampelokipoi) is projected versus the surface elevation in metres. Characteristic points along the section: (1) Diavolorema, (2) Aghia Sophia, Psychiko, (3) Crossing with Kifissia Ave., (4) Crossing with Sp. Louis Ave., (5) SELETE area, (6) Crossing with Attica Road, (7) Herakleio at the deepest wells, (8) Perpendicular galleries in aquifer at Koukouvaounes, (9) Marls-Red Sediments contact.

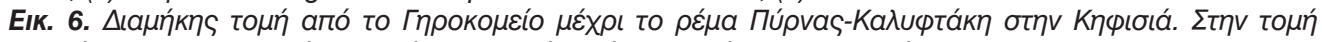

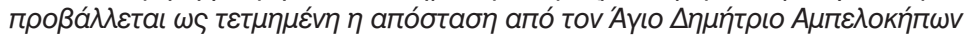

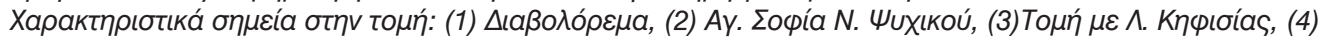

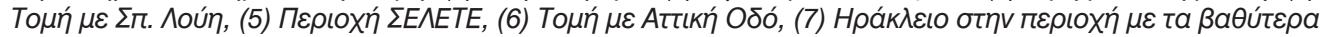

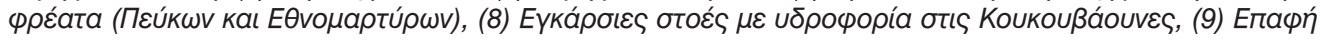
$\mu a \rho \gamma \omega ́ v-\varepsilon \rho u \theta \rho \omega ́ v ~ \iota \zeta \eta \mu a ́ t \omega v$. 


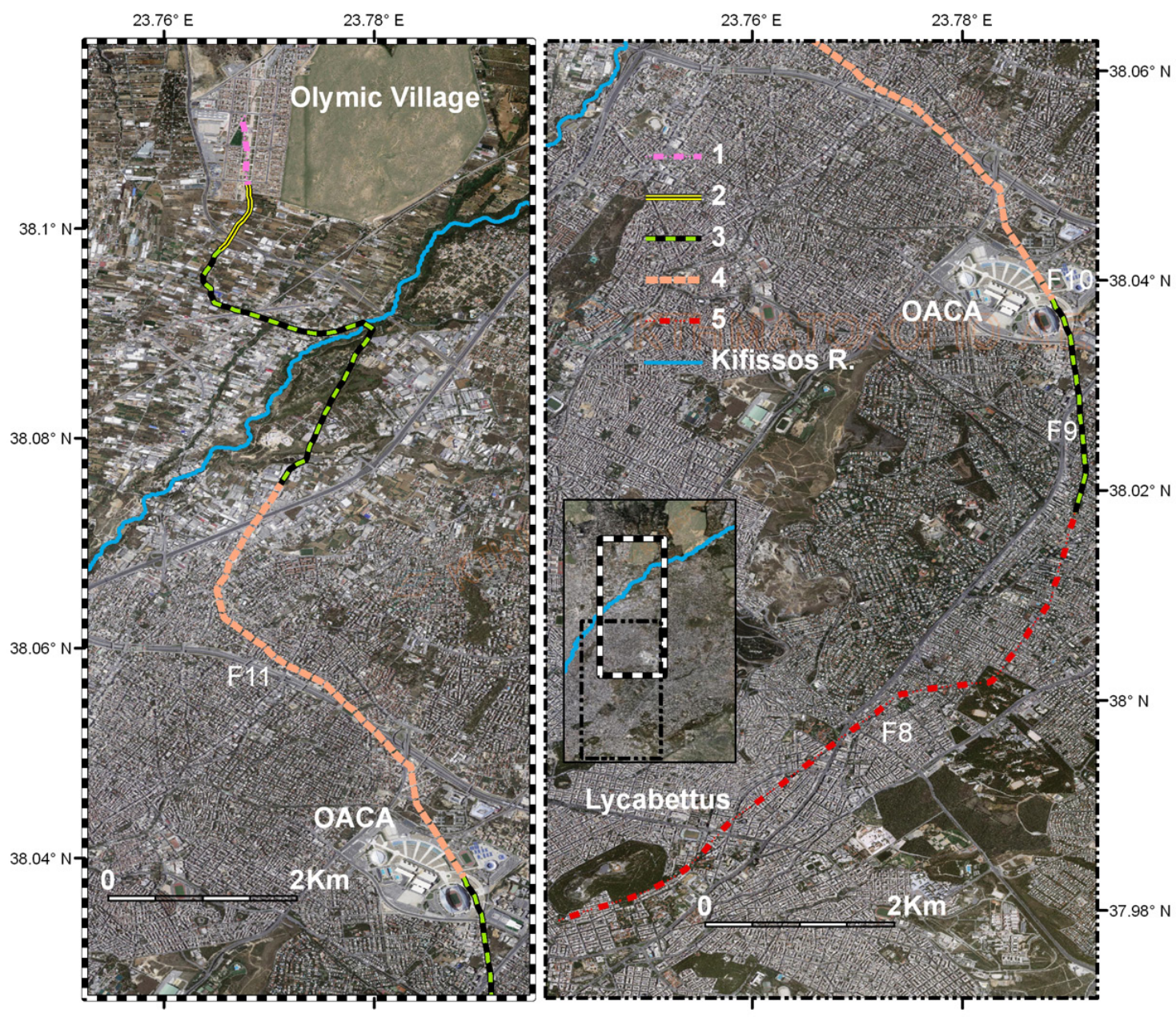

Fig. 7. The geological formations along the Hadrianic tunnel: (1) Quaternary talus cone, (2) Older talus cones, (3) Pikermian Red Sediments, (4) Kalogreza Miocene sediments with lignites, (5) Athenian Schists. F8 to $F 11$ are the locations of the sections presented in Figs 8 to 11 respectively.

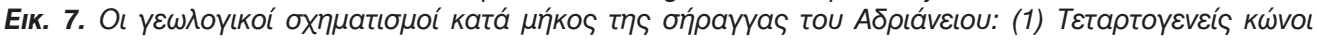

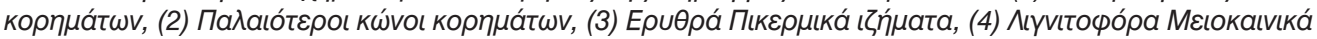

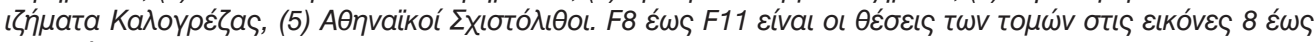
11 avtíotolxa.

The geological formations along the Hadrianic tunnel are drawn in Fig. 7 on the basis of the geological maps of the Greek Institute of Geological and Mineral Exploration (IGME); the delineation between the Neogene and the overlying Pikermian Red Sediments in the OAKA area is based on sam- pling boreholes by "EDAFOS Consultants Ltd" (2001). Starting with talus cones in the Olympic Village, the tunnel passes through the Kifissos Red Sediments, the marly lacustrine Neogene sediments with lignites, the Pikermian Red Sediments and the Athenian Schists. 


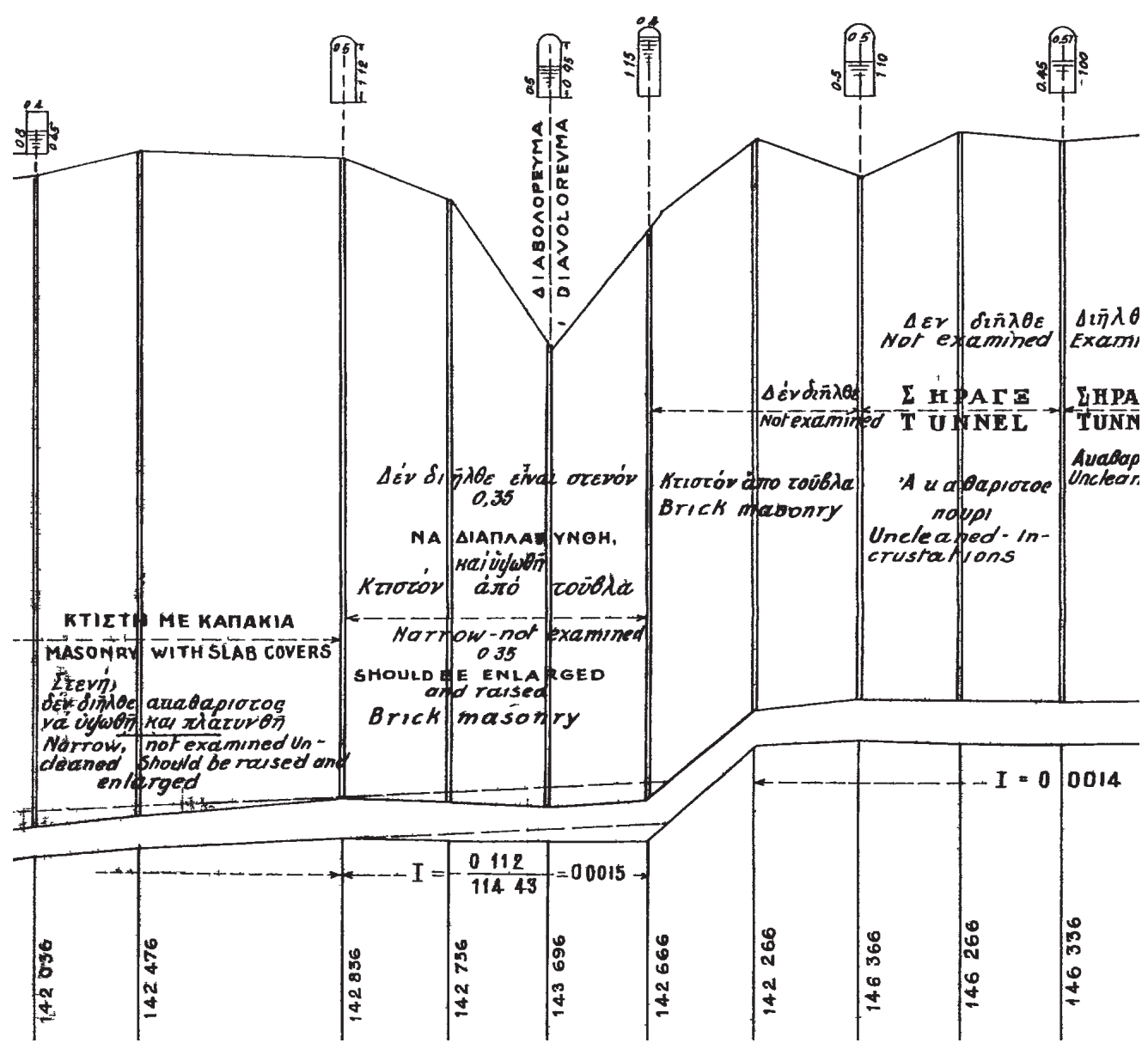

Fig. 8. Section of the Hadrianic tunnel in Athenian Schists, in a drawing of EYDAP from the beginning of the last century (location F8 in Fig. 7).

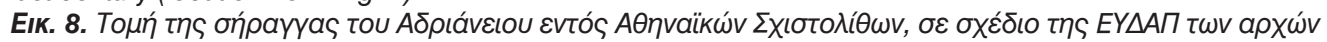

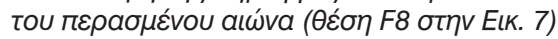

In the following, the state of the tunnel will be presented on representative sections through the above geological formations (Figs 8 to 11 indicated as F8 to F11 respectively on Fig. 7).

Part of the section at Diavolorema in Athenian Schists with comments for the state and the support of the tunnel in drawings from the beginning of the last century are shown in Fig. 8.

The elevation of the floor, the hydraulic gradient, I, the wells, the tunnel sec- tion with the water level and the surface relief are also noted. The stability problems are in general very serious in the Schists, where slope inversion, silt deposition and narrowing of the section are observed, making passage impossible very often.

The crucial collapse of the Hadrianic tunnel in antiquity occurred at Agios Dimitrios in the Schists of Athens, most likely before the construction of the Late Roman aqueduct in the 5th cen- 
tury AD. After the tunnel caving, water continued to surge from the tunnel like a "spring". Another subsidence was recorded in 1923 at Psychiko (Georgalas, 1930), again in the Schists of Athens. Strangely enough, Georgalas was very critical about the importance of the Hadrianic aqueduct and wrote that: "the (engineering) work, which many people and some educated, reached the point to praise as the peak of the Roman art does not have a scientific and blameless initial construction".

This risky behaviour of the Athenian Schists can be understood from the experience of modern geotechnical works. It is a heterogeneous metamorphic flyschoid formation with weak members and sheared zones due to the intensive Apline compressive tectonism. The formation usually comprises two distinct horizons (Marinos et al., 1997; 1997b): The upper horizon consists mainly of interbedded sericitic sandstones, marly limestones and breccia-conglomerates. This formation is mostly coarse-grained, has a yellowish-brown color ("brown schist") and its thickness varies between a few meters and about 25 meters.

The lower horizon consists mainly of graphitic and chloritic phyllites, alternating with meta-sedimentary shales. The material has usually a dark grey to green-grey color ("black schist") and is characterized by a pronounced higher proportion of shale-like, fine-grained sediments compared to the mainly coarse-grained materials of the upper horizon. In many locations, the "black schist" is severely weathered, mylonitic and slickensided. The transition from the upper to the lower unit, if not sharp due to tectonic shears, is usually gradual, with the coarse-grained sediments becoming less widespread with depth. The knowledge of the engineering be- haviour of the formation is greatly based today on practical experience gained from shallow excavations for building foundations and excavations from the Athens Metro construction. The failure mechanism of the upper unit consists in roof overbreaks in fractured zones, resulting subsequently in chimney failures. They are faced today by the implementation of anchors together with a layer of shotcrete. If the rock mass is heavily fractured, forepoling with spiles and light steel ribs are usually applied. The strength of the lower unit is low, and the behaviour is a soil like one. Even at depths of a few tens of meters, it has a plastic behaviour and a tendency for immediate collapse. Today, in a conventional construction before the final lining, a robust shell of temporary support during the construction is needed, with close spaced steel ribs well embedded in shotcrete. At shallow depths a forepoling umbrella is often used. The lower unit of the Athenian Schist may also have a time-dependent behaviour and exhibits a slowly evolving deformation due to creep. Although the phenomenon is mild due to the shallow depth, it can provoke a deformation of the initial section of the tunnel and arrive even at a final collapse. Today these deformations due to plastic behaviour and creep are faced by a reinforced concrete lining or by a lining of precast ring segments in the case of a mechanized excavation with a tunnel boring machine (TBM). In antiquity the tunnels were maintained stable during the excavation works, thanks to their immediate support. However, the circulation of water on the rocks surrounding the tunnel could not be prevented; and in the case of the Athenian Schists the rock was subject to creep, causing plastic deformation and distortion of the tunnel geometry. 


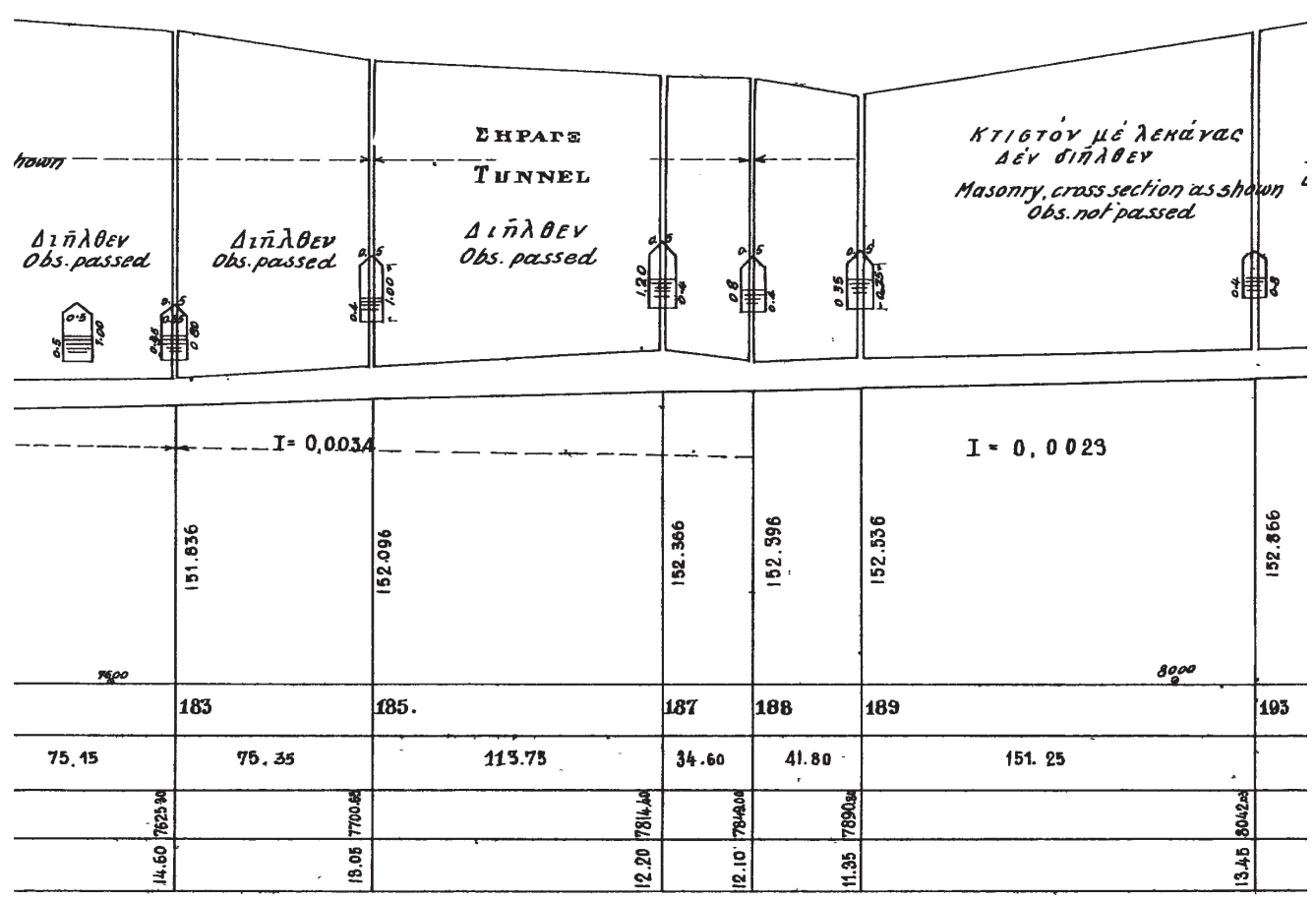

Fig. 9. Section of the Hadrianic tunnel in red argillaceous sediments, in a drawing from the beginning of the last century (location F9 in Fig. 7).

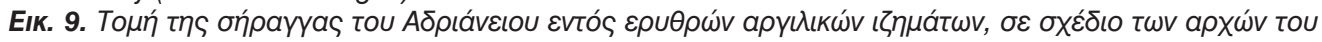

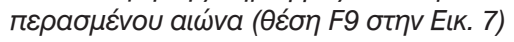

The Hadrianic tunnel is in a better state in the red argillaceous sediments, where local undulations and roof overbreaks are limited (Fig. 9). It is known from the geotechnical works in OAKA that the argillaceous sediments are overconsolidated, mixed with silt and sand (Tolis et al., 2006) and therefore creeping was not favoured at these depths.

The state of the Hadrianic Aqueduct is rather good in the marls (Fig. 10), it varies however depending on the occurrence of either argillaceous-marly members or calcareous marls; thus, plastic deformation or fracturing could occur respectively. The section of the tunnel in Fig. 10 is stable in general, however the rock locally is densely fractured and part of the tunnel had collapsed; the solution given during the resumption of the work was the semicircular bypass of the collapsed main tunnel.

The geotechnical behaviour of the marls is improved in the presence of calcareous or sandy components; in this case fracturing due to local faulting might be a problem. Excavation is easy but support is required. Marls are not as weak as the Schists of Athens, since they have not been subjected to the orogenic compression. Argillaceous marls however could also undergo plastic deformation and light creep.

The marly limestones are the most competent rock along the Hadrianic tunnel and they were left mostly unsupported. Apart from the potential hazard because of fracturing, a side effect can happen 
due to the deposition of calcite in the form of incrustation at the edges of the floor (Fig. 11); thus the dimensions of the tunnel are diminished and access is obstructed.

\subsection{The stability of the Hymettos aqueduct}

Ziller (1877) had already noticed that the wells of the aqueduct in the Garden had been filled by silt and that the tun-

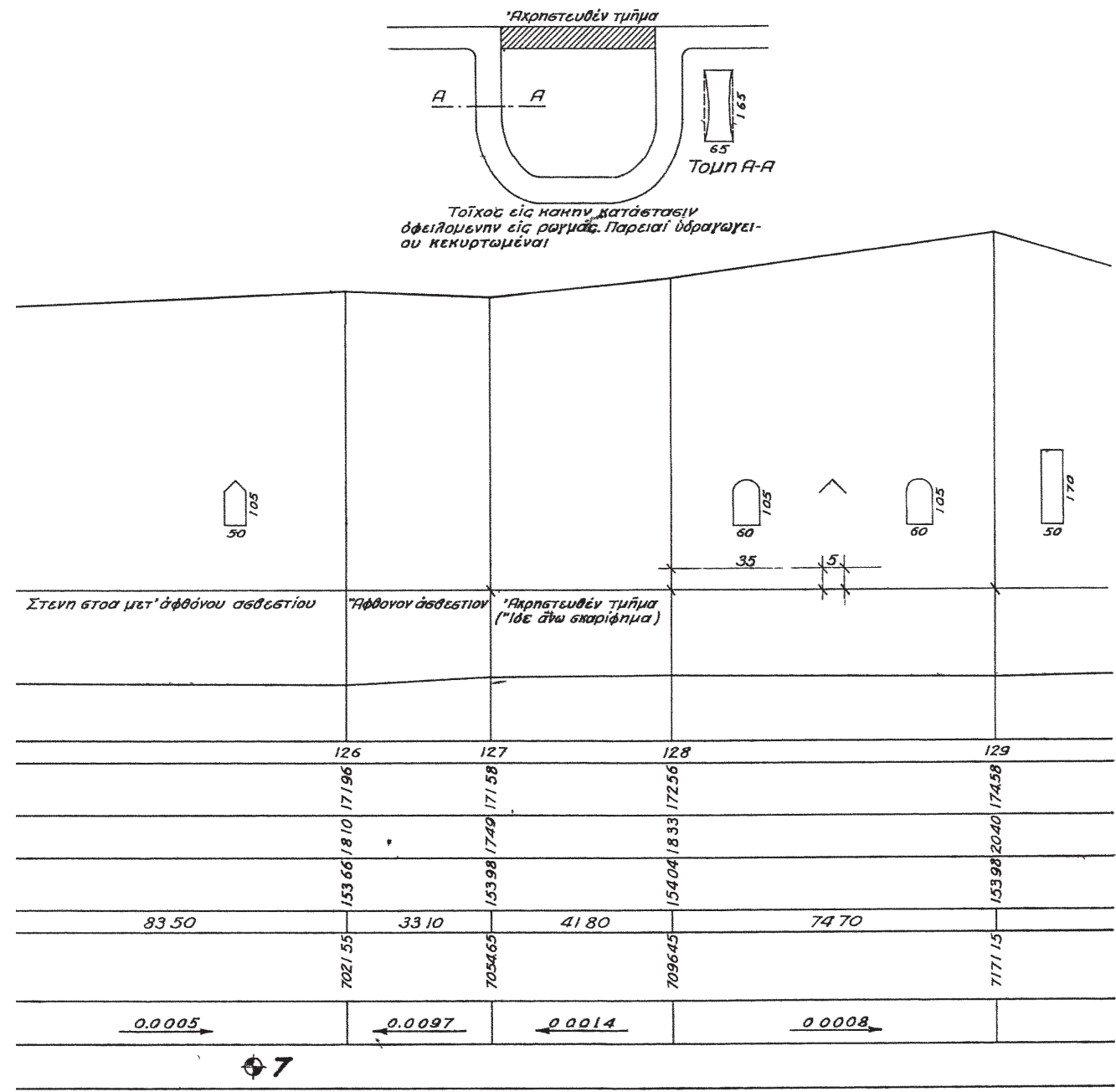

\section{'AdpIäveloV "YoparareT́N

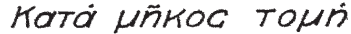

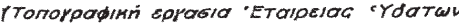 \\ ФUंกतก๊ $\sigma$}

Fig. 10. Section of the Hadrianic tunnel in marls, in a drawing from the beginning of the last century (location F10 in Fig. 7); the bypass of the tunnel due to subsidence is also shown.

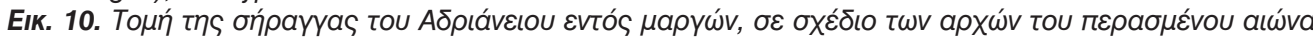

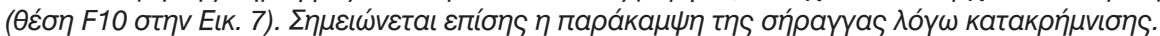




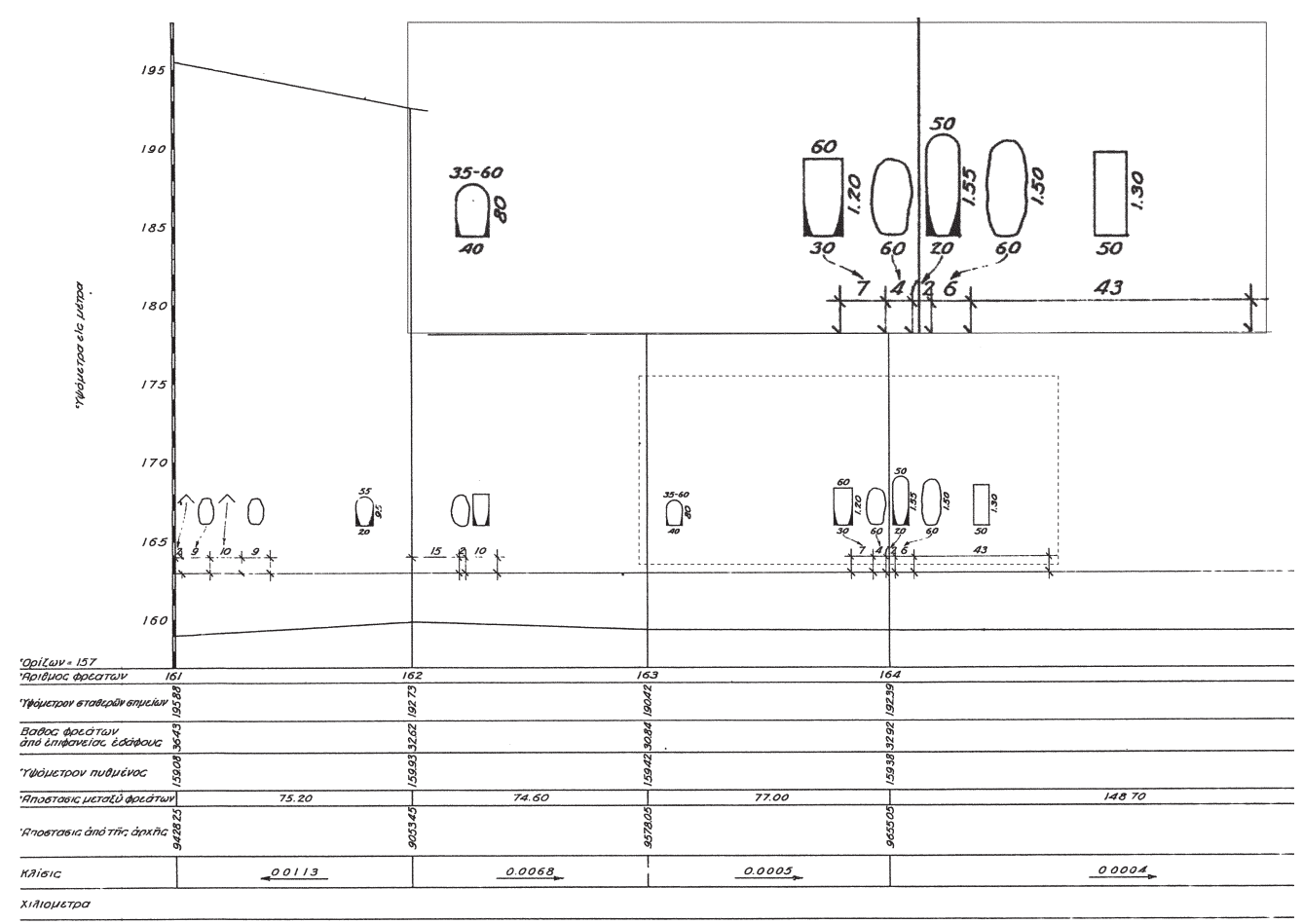

Fig. 11. Section of the Hadrianic tunnel in marly limestones, in a drawing from the beginning of the last century (location F11 in Fig. 7); on the top: enlargement of the central part with deposition of travertine.

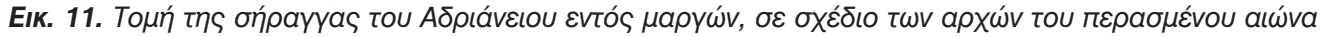

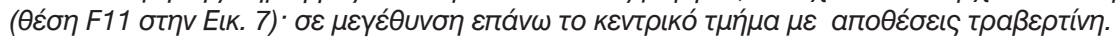

nel had been blocked near the Russian Church; no wonder that this occurred again in the Schists of Athens.

Furthermore, the Metro tunnel passed through this area in 1996 and had a serious subsidence associated with the formation of a crater on the ground, when an ancient aqueduct was crossed. The ground consisted of the weakest unit of the Athenian Schists. The event and the archaeological findings have been described in detail (Lygouri-Tolia, 2000). It seams that the collapse was caused by the infiltration of water from the ancient aqueduct into the underlying Metro tunnel within a period of a couple of days, when the Tunnel Boring Machine was temporarily stopped at this location.

It is worth mentioning that part of an ancient tunnel, about $150 \mathrm{~m}$ long, and two wells were crossed along the Metro line, as shown in Fig. 2. This ancient tunnel correlates very well with the hypothetical extension of the aqueduct of the Garden after Ziller; however, the situation of the ancient hydraulic works in the National Garden is more complicated and further evaluation is necessary. The line of the Hymettos aqueduct in the National Garden in Fig. 2 is an approximation of the main tunnel, drawn on the basis of both Ziller's data and findings in the Metro excavation; there are however indications of local ramifi- 
cations deviating from the main tunnel. It is concluded that the parts of the tunnels of both the Peisistratean and the Hadrianic aqueduct in the zone of the Athenian Schists could not survive for long without careful support and regular maintenance of the walls.

\section{Epilogue}

The water supply had always been a difficult task in Attica, a land with dry Mediterranean climate associated with frequent and long periods of drought. It is noted just for comparison that water is transported to modern Athens from reservoirs more than $300 \mathrm{~km}$ away. A continuous improvement of the engineering solutions applied in the ancient aqueducts is revealed; younger aqueducts advance older techniques and carry water from more distant sources. A sequence of aqueducts which capture underground water was finally followed by surface transport of water from springs, in the $5^{\text {th }} C$. $A D$, when Athens declines in population.

Intelligent local sustainable solutions were invented in antiquity which still remain effective. Both, the Hadrianic and the Hymettos aqueducts continue to drain underground water all along their route to Athens from the Parnitha and Hymettos Mountains respectively. In both cases the floor of the tunnel is below the water table over a considerable length and groundwater is also captured through wells at regular distances along the tunnel.

Furthermore, the small dimensions of the works and the support of the walls contributed to the preservation of the tunnels over their major extent, although failure was unavoidable locally. The descriptions of the state of the Hadrianic aqueduct in the EYDAP drawings of the last century are so elo- quent that they might substitute a pilot tunnel.

The stability problems of the Hadrianic aqueduct are apparently related mainly to weak formations and the lower unit of the Athenian Schists in particular, therefore they have a rather regional character; in a few cases they are associated with intensive faulting and are of local nature. The limited possibilities of support in antiquity were inadequate to cope with the stability problems in creeping formations with time dependent deformations, similar to the clay like sheared formations of the lower unit of the Schists of Athens. This was faced with the use of concrete for the support of the tunnel during the resumption of the work in the last century, which was a great improvement.

Modern techniques allow very good evaluation of the geotechnical conditions in advance, for the safe excavation and support of loose and weak formations, as well as good command of the failure mechanisms and quantitative monitoring during the operation of the geotechnical works. The experience from the construction of the Metro suggests that a reliable geological model of the tunnel itself and the surrounding area is required for the minimization of the so called unpredictable risk.

\section{Acknowledgments}

Sincere thanks are expressed for their kind contribution with comments and/ or data to Prof. A.G. Anagnostopoulos, E. Nestoridou, Director at EYDAP, Dr. $S$. Kavounidis and EDAFOS Consultants Ltd, M. Benissi and M. Novack, Eng.Geolog. Section, Attico Metro S.A. and to the Archaeologists E. LygouriTolia, D. Palaeologos and M. Stephanopoulou. Figs 4 and 7 were plotted on air photos of Ktimatologion S.A. 


\section{References}

Camp, J., McK. II, 1977. The water supply of ancient Athens from 3000 to $86 \mathrm{BC}$, Ph.D. Thesis, Princeton Univ., New Jersey, USA, 357pp.

Camp, J., McK. II, 1982. Drought and famine in the 4th century BC. Hesperia Supplements, 20, Studies in Athenian Architecture, Sculpture and Topography, 9-17.

Chiotis, E., 2011. Aqueducts and drainage works in the ancient Agora of Athens. In Giannikouri, A., (ed), The Agora in the Mediterranean from Homeric to Roman times, Giannikouri, A. (Ed.), Ministry of Culture, Athens, 165-180.

Chiotis, E., Chioti, L., 2011. Industrial activities in the ancient Agora of Athens in the Late Roman times. In: Giannikouri, A., (Ed), The Agora in the Mediterranean from Homeric to Roman time. Giannikouri, A. (Ed.). Ministry of Culture, Athens, 181-196.

Chiotis, E.D., Chioti, L.E., 2012. Water supply of Athens in the antiquity. In: Angelakis, A.N., Mays, L.W., Koutsoyiannis, D., Mamassis, N. (Eds), Evolution of Water Supply Through the Millennia. IWA Publishing, 407-442

Cordellas, A., 1879. Athens examined from the point of view of hydraulics. Athens, 172pp.

EDAFOS Consultants Ltd, 2001. OAKA: Geotechnical Investigation and Study, Technical Report [in Greek].

Georgalas, G.K., 1930. Water Supply of Athens. "Pyrsos" Encyclopedia, 234236. [in Greek].

Horne, R.J., 2009. Athens 2004 Olympic Village: the underground section, http://athens123.com/Main_HTML/ Hadrians-Aqueduct/hadrians-aqueduct olympic-village-underground. html

IGME (Institute of Geology and Mineral Exploration), Geological Map of
Greece 1:50,000, Sheets AthensEleusis, Kifissia, Koropi-Plaka, Athens-Peiraias.

Kovacs, M.G., 1989. The Epic of Gilgamesh. Stanford University Press, Stanford, California,USA.

Lygouri-Tolia, E., 2000. Evangelismos Station. In: Parlama, L., Stambolodis, N. (Eds), The City under the City. Museum of Cycladic Art, Athens, Greece, 208-217.

Marinos, G.P., Katsikatsos, G., Georgiades-Dikaioulia, E., Mirkou, R.,1971. The Athens' Schists Formation I: Stratigraphy and Structure. Annales Géologiques des Pays Helléniques, Athens, Greece, 23, 183-216 [in Greek].

Marinos, P., Blanke, J., Novack, M., Benisi, M., Rovolis, G., 1997. Geological and environmental considerations for selecting an Athens Metro tunnel alignment beneath an important archaeological area. In: Marinos, P. et al. (Eds), Engineering Geology and the Environment. Proceedings of an International Symposium of IAEG. Balkema Publisher, Athens, 27772784

Marinos, P., Benisi, M., Novack, M., Rovolis, G., Papadatos, I., Antoniou, A., 1997. Engineering geological assessment of the "Athens schist" for TBM excavation of the Athens metro. Proceedings of the International Symposium on Geology and Environment, Istanbul, 145-151.

Paraskevopoulos, G.P., 1907. The Mayors of Athens (1835-1907). Athens, reprinted in 2001, Municipality of Athens, 607pp., [in Greek].

Platonos-Yiota, M., 2004. ACHARNAI, Historical, and topographic overview of Ancient Acharnai, of the neighbouring Municipalities and the Parnitha fortifications, Municipality of 
Acharmai, Athens. Greece, 539 pp. [in Greek].

Siemos, N., Michalaki, I., 2009. Hydrogeological Survey of Attica and the suburban area of Thrakomakedones, 2009. Internal Report, Institute of Geology and Mineral Exploration, $55 \mathrm{pp}$. [in Greek].

Stevens, G.P., 1946. The northeast corner of the Parthenon. Hesperia, 15, 1-26.

Tamvakis, N., 2005. The Peisistratean Aqueduct and the National Garden. The Nature, 110, 33-36 [In Greek].

Tölle-Kastenbein, R., 1994. Das archaische Wasserleitungsnetz für Athen und seine späteren Bauphasen (The archaic net of water conduits for Athens and its later construction phases). Mainz am Rhein, 120 pp.
Tolis, S.B., Kavounidis, S., Bardanis, M.E., 2006. Geotechnical Characteristics of the Maroussi Clay. $5^{\text {th }}$ Panhellenic Conference on Geotechnical and Geoenvironmental Engineering, TEE, Xanthi, 1-8 [in Greek].

Vanderpool, E., 1965. The Acharnian Aqueduct, Xapıotńpıov Eıৎ A.K. Opגávסov (Honorary Volume in Memory of A.K. Orlandos), 1, 166-174.

Vrellis, Gr., 2010. Evaluation of a pumping test of the borehole at the edifice of IGME. Internal Report, Institute of Geology and Nineral Exploration, 17 pp. [In Greek].

Ziller, E., 1877. Untersuchungen über die antiken Wasserleitungen Athens (Exploration of the ancient aqueducts of Athens). Mitteil. Deutsch. Arch. Inst., Athen. Abteilung, 2, 107-131. 